\title{
Autocrine human GH promotes radioresistance in mammary and endometrial carcinoma cells
}

\author{
Nicola M Bougen ${ }^{1,3}$, Michael Steiner ${ }^{1}$, Mikhail Pertziger ${ }^{1}$, Arindam Banerjee ${ }^{1}$, \\ Severine E Brunet-Dunand ${ }^{1}$, Tao Zhu', ${ }^{2}$, Peter E Lobie ${ }^{1,3}$ and Jo K Perry ${ }^{1}$
}

\author{
${ }^{1}$ The Liggins Institute, University of Auckland, 2-6 Park Avenue, Private Bag 92019, Auckland 1023, New Zealand \\ ${ }^{2}$ Hefei National Laboratory for Physical Sciences at Microscale and School of Life Sciences, University of Science and Technology of \\ China, Hefei, Anhui 230027, People's Republic of China \\ ${ }^{3}$ Cancer Science Institute of Singapore and Department of Pharmacology, National University of Singapore, Singapore 117456, \\ Singapore
}

(Correspondence should be addressed to J K Perry; Email: j.perry @ auckland.ac.nz)

\begin{abstract}
Although recent advances in breast cancer treatment regimes have improved patient prognosis, resistance to breast cancer therapies, such as radiotherapy, is still a major clinical challenge. In the current study, we have investigated the role of autocrine human $\mathrm{GH}(\mathrm{hGH})$ in resistance to ionising radiation (IR)-based therapy. Cell viability and total cell number assays demonstrated that autocrine hGH promoted cell regrowth in the mammary carcinoma cell lines, MDA-MB-435S and T47D, and the endometrial carcinoma cell line, RL95-2, following treatment with IR. In addition, autocrine hGH enhanced MDA-MB-435S and T47D cell clonogenic survival following radiation exposure. The enhanced clonogenic survival afforded by autocrine hGH was mediated by JAK2 and Src kinases. Investigation into the DNA repair capacity demonstrated that autocrine hGH reduced IR-induced DNA damage in MDA-MB-435S and T47D cells. Functional antagonism of hGH increased RL95-2 sensitivity to IR in cell viability and total cell number assays, reduced clonogenic survival and enhanced the induction of DNA damage. Thus, autocrine hGH reduced sensitivity to treatment with IR in mammary and endometrial carcinoma cell lines in vitro, while functional antagonism of $\mathrm{hGH}$ sensitised endometrial carcinoma cells to IR. Functional antagonism of $\mathrm{hGH}$, used in conjunction with radiotherapy, may therefore enhance treatment efficacy and improve the prognosis of patients with breast and endometrial cancer.
\end{abstract}

Endocrine-Related Cancer (2012) 19 625-644

\section{Introduction}

Radiotherapy is a frontline therapy used in the treatment of breast cancer and is used to treat the majority of patients with invasive breast cancer or ductal carcinoma in situ. Exposure of tumour cells to ionising radiation (IR) promotes cell death through the induction of DNA damage and results in a range of lesions including single-strand breaks and highly lethal double-strand breaks (DSBs; Jeggo \& Lobrich 2006). Generation of DNA lesions activates DNA damage checkpoint pathways and subsequent DNA repair networks that are central to the cellular response to IR (Branzei \& Foiani 2008). Resistance to radiation therapy is a major clinical obstacle; tumour response to radiation can vary considerably, even in tumours displaying similar pathology.

Numerous extrinsic and intrinsic factors contribute to reduced cellular sensitivity to IR. The extent of tumour hypoxia is one well-established extrinsic factor affecting radioresponse; viable cells in hypoxic areas are more resistant to IR-induced cell death than normoxic cells (Gray et al. 1953, Nordsmark et al. 2005), a consequence of reduced DNA damage in hypoxic regions. Intrinsic factors include an enhanced capacity of cells to repair DNA damage, which can occur through alteration in the expression or activity of DNA repair enzymes (Dumont et al. 2009, Dutreix et al. 2010), cell cycle checkpoint control; the 
activation of signal transduction cascades involved in tumour cell proliferation and survival such as the phosphatidylinositol 3-kinase (PI3K) pathway and mitogen-activated protein kinase (MAP kinase) pathway (Jameel et al. 2004, Begg et al. 2011), and through variation in the cellular concentration of thiols (e.g. glutathione and cysteine; Estrela et al. 2006). Increased expression in tumour cells of autocrine growth factors and growth factor receptors such as vascular endothelial growth factor (VEGFA), insulinlike growth factor 1 receptor (IGF1R) and members of the human epidermal growth factor receptor (HER) family have been demonstrated to promote radioresistance through multiple mechanisms (Jameel et al. 2004, Dumont et al. 2009, Zaidi et al. 2009).

Accumulating evidence indicates a role for human GH (hGH) in human cancer (Perry et al. 2006, 2008, Kleinberg et al. 2009, Brooks \& Waters 2010, Harvey 2010, Gallagher \& Leroith 2011). Recent studies have demonstrated that humans with GH receptor (GHR) deficiency are protected from developing cancer (Shevah \& Laron 2007, Gallagher \& Leroith 2011, Guevara-Aguirre et al. 2011, Steuerman et al. 2011); two recent studies observed that individuals with Laron syndrome, which results from a defect in the GHR, have a greatly reduced, almost absent, risk of cancer compared with individuals from the same family without the receptor deficiency (Guevara-Aguirre et al. 2011, Steuerman et al. 2011). While studies investigating hGH expression in human breast and endometrial cancer have demonstrated that hGH expression is associated with specific histopathological features and survival outcomes for patients (Slater et al. 2006, Wu et al. 2011). In mammary carcinoma, hGH expression is positively correlated with lymph node metastasis, tumour stage, HER-2 status and proliferative index (Wu et al. 2011). Increased hGH expression has also been implicated in the pathogenesis of endometriosis and endometrial adenocarcinoma (Ayalon et al. 1982, Slater et al. 2006, Yurkovetsky et al. 2007, Pandey et al. 2008, Wu et al. 2011) and in endometrial carcinoma is associated with increased FIGO grade, myometrial invasion and ovarian metastases (Wu et al. 2011).

In recent studies, we have demonstrated that autocrine hGH promotes cell proliferation, cell survival and oncogenicity of human mammary epithelial and endometrial carcinoma cells, enhancing anchorage-independent cell growth and supporting tumour formation in immunodeficient mice (Zhu et al. 2005a, Pandey et al. 2008). Autocrine hGH also promotes cell migration/invasion and epithelial to mesenchymal transition in both mammary and endometrial carcinoma cell lines (Mukhina et al. 2004, Pandey et al. 2008).

A radioprotective role for hGH has been suggested by cell culture and in vivo studies. Treatment of Chinese hamster ovarian (CHO-4) cells stably expressing the GHR with exogenous hGH protects them from cell death induced by $\gamma$-irradiation or the radiomimetic drug bleomycin in a dose-dependent manner (Madrid et al. 2002). Treatment of irradiated rat pituitary cells or human peripheral blood lymphocytes with recombinant GH increases cell survival (Chiarenza et al. 2000, Lempereur et al. 2003). While protection from radiation-induced apoptosis has also been observed in cell cultures derived from the rat embryonic brain cortex treated with GH-enriched media (Isla et al. 2002).

Administration of GH has also been demonstrated to be radioprotective in animal studies (Gomez-de-Segura et al. 1998, Vazquez et al. 1999, Mylonas et al. 2000, Raguso et al. 2002, Morante et al. 2003, Tekin et al. 2006, Isla et al. 2007, Chen et al. 2010). Treatment of rats with GH prevented body weight loss and decreased mortality following abdominal $\gamma$-irradiation (Gomez-de-Segura et al. 1998) and enhanced intestinal mucosal integrity (Alexandrides et al. 1998, Gomez-de-Segura et al. 1998). This protective effect following radiation was associated with decreased intestinal mucosal cell apoptosis (Mylonas et al. 2000, Morante et al. 2003) and an increased proliferative index (Gomez-de-Segura et al. 1998, Morante et al. 2003). hGH administration was also demonstrated to protect normal rat intestinal tissue from radiotherapyinduced damage but not implanted adenocarcinoma cells (Morante et al. 2003). Furthermore, rats pretreated with $\mathrm{GH}$ before radiation exposure had decreased severity of radiodermatitis, a frequent complication of radiotherapy (Tekin et al. 2006). Such studies have led to the suggested clinical value of $\mathrm{hGH}$ in reducing radiation-induced toxicity.

There is less direct evidence in humans that hGH protects against radiotherapy-induced cell death, although one study found that elevated levels of expression $h G H R$ mRNA and protein are associated with a poor response to radiotherapy in rectal cancer (Wu et al. 2006). Increased hGHR expression was also observed following treatment with radiotherapy when compared with pre-radiation samples (Wu et al. 2006).

As described, the majority of studies have investigated a radioprotective effect for exogenous $\mathrm{GH}$ on normal cells and tissues with the aim of reducing radiation-induced toxicity. As endogenous hGH expression is observed in a proportion of breast and endometrial tumours (Slater et al. 2006, Wu et al. 2011), we hypothesised that autocrine expression of 
hGH would reduce cancer cell sensitivity to radiationinduced cell death, thus potentially reducing the effectiveness of radiotherapy. In this study, we investigated the effect of autocrine hGH on mammary carcinoma and endometrial carcinoma cell radiosensitivity and demonstrate that autocrine hGH reduces mammary carcinoma cell sensitivity to treatment with IR, while functional antagonism of hGH in endometrial carcinoma cells sensitises cells to IR and enhances IR-induced cell death, thus identifying compounds that antagonise the hGHR as potential radiosensitising agents.

\section{Materials and methods}

\section{Cell lines and cell transfection}

Two breast cancer cells lines (MDA-MB-435S and T47D) and an endometrial cancer cell line (RL95-2) were used in this study. MDA-MB-435S and T47D cells were cultured at $37{ }^{\circ} \mathrm{C}$ in $5 \% \quad \mathrm{CO}_{2}$ in RPMI (Gibco) supplemented with $10 \%$ heat-inactivated FBS, $100 \mathrm{U} / \mathrm{ml}$ penicillin, $100 \mu \mathrm{g} / \mathrm{ml}$ streptomycin and $2 \mathrm{mM}$ L-glutamine. RL95-2 wild-type and stable cell lines (vec and hGH) were cultured at $37^{\circ} \mathrm{C}$ in $5 \% \mathrm{CO}_{2}$ in Advanced DMEM/F-12 (Invitrogen) supplemented with $10 \%$ heat-inactivated FBS, $100 \mathrm{U} / \mathrm{ml}$ penicillin, $100 \mu \mathrm{g} / \mathrm{ml}$ streptomycin and $2 \mathrm{mM} \mathrm{L}$-glutamine (Gibco).

MDA-MB-435S, T47D and RL95-2 cells stably transfected with an expression plasmid containing the wild-type $h G H$ gene, $G H 1$ (pcDNA3-hGH), under the control of a CMV promoter (cell lines designated MDA-hGH, T47D-hGH and RL95-hGH) have been described previously (Pandey et al. 2008, Bougen et al. 2011). It should be noted that the stably transfected MDA-MB-435S cell lines were originally reported to be derived from MDA-MB-231 cells (Bougen et al. 2011); however, recent short tandem repeat testing has identified that this cell line is MDA-MB-435S. The control cell lines are stably transfected with the empty pcDNA3 vector (cell lines designated MDA-vec, T47D-vec and RL95-vec). Pooled stable transfectants were used to minimise any effect of potential clonal selection.

For functional inhibition of hGH, the hGHR antagonist, B2036 (Pfizer, Chesterfield, MD, USA), was added to the medium $(1000 \mathrm{nM})$ and media replaced every 2 days. Exogenous hGH was added to the medium at $0-100 \mathrm{nM}$ and media replaced every 2 days. BSA (Sigma-Aldrich) was used as a protein control at equivalent concentrations where appropriate.
The following small molecule inhibitors were used: JAK2 inhibitor, AG490 $(50 \mu \mathrm{M})$; c-SRC inhibitors, PP1 $(20 \mu \mathrm{M})$ and PP2 $(20 \mu \mathrm{M})$ and the inactive structural analogue control, PP3 $(20 \mu \mathrm{M})$; all from Merck.

\section{Extraction of RNA and semiquantitative RT-PCR}

RNA extraction and semiquantitative reverse transcriptase (RT)-PCR was carried out as described previously (Amiry et al. 2009). Amplified RT-PCR products were visualised on a $1.5 \%$ agarose gel. The sequences of the nucleotide primers used in real-time PCR (qPCR) are provided in Table 1.

\section{Real-time PCR analysis}

For quantitative real-time PCR, total RNA was converted to cDNA using SuperScript III First-Strand Synthesis SuperMix for qRT-PCR (Invitrogen) as per manufacturer's instructions. Real-time PCR analysis was performed using an ABI 7900 real-time PCR system (Applied Biosystems, Foster City, CA, USA). Multiple gene markers distributed around the genome and three housekeeping genes were used for real-time PCR analysis using the SYBR GreenER qPCR SuperMix for ABI PRISM (Invitrogen). $5 \mathrm{ng}$ total cDNA isolated from each stable cell line was added to a $20 \mu \mathrm{l}$ reaction containing SYBR GreenER qPCR SuperMix for ABI PRISM and $200 \mathrm{nM}$ of each primer. Triplicate reactions were performed for each marker in a 384-well plate using a two-step amplification program of initial denaturation at $95{ }^{\circ} \mathrm{C}$ for $10 \mathrm{~min}$, followed by 40 cycles of $95^{\circ} \mathrm{C}$ for $20 \mathrm{~s}$ and $60{ }^{\circ} \mathrm{C}$ for $30 \mathrm{~s}$. A melting curve analysis step was carried out at the end of the amplification, consisting of denaturation at $95{ }^{\circ} \mathrm{C}$ for $1 \mathrm{~min}$ and re-annealing at $55^{\circ} \mathrm{C}$ for $1 \mathrm{~min}$. The geometric mean of $\mathrm{Ct}$-value for each reaction was calculated. Amplification efficiencies were calculated according to the equation $E=10^{(-1 / \text { slope })}$ and ranged from 90 to $104 \%$ for all gene markers; no unspecific amplification or primer dimer was observed in any of the reactions as confirmed by the melt curve analysis.

Each change in gene expression is expressed as 'fold change' and is the average of three replicates. Positive and negative fold change indicates a respective increase or decrease in mRNA levels. To compensate for potential differences between markers, the relative expression was computed, based on the efficiency $(E)$. Gene of interest (GOI) expression was normalised by reference genes (REF): $\beta$-actin and GAPDH.

Relative expression and fold change were calculated using the formulae: 
Relative expression (RE) $)_{\text {Control }}=\frac{\left.\left(E_{\mathrm{GOI}}\right)^{\left(C t_{\mathrm{GOI} \text { Control }}-C t_{\mathrm{GOI}} \text { Test }\right.}\right)}{\left.\left(E_{\mathrm{REF}}\right)^{\left(C t_{\mathrm{REF}} \text { Control }-C t_{\mathrm{REF}} \text { Test }\right.}\right)}$

Fold change $\mathrm{R}_{\mathrm{RE}>1}=\mathrm{RE}$

Fold change $\mathrm{RE}_{\mathrm{RE}}=\frac{1}{\mathrm{RE}}$

Changes in relative expression $>1.5$-fold were taken as significant.

\section{Western blot analysis}

Western blot analysis was carried out as described previously (Mertani et al. 2001) using the following antibodies: Rad-51 (Abcam, Inc., Cambridge, MA, USA; 1:1000) and anti-mouse secondary antibody conjugated to HRP (Sigma-Aldrich, 1:2000). Blots were stripped and re-probed using a $\beta$-actin antibody (Santa Cruz Biotechnology, Santa Cruz, CA, USA; 1:20 000) as a loading control.

Table 1 The sequences of the oligonucleotide primers and methods used for quantitative real-time PCR

\begin{tabular}{|c|c|c|c|}
\hline Gene & Symbol & Primer sequence $\left(5^{\prime}-3^{\prime}\right)$ & Amplicon size (bp) \\
\hline Ataxia telangiectasia mutated & ATM & $\begin{array}{l}\text { For: TGGATCCAGCTATTTGGTTTGA } \\
\text { Rev: CCAAGTATGTAACCAACAATAGAAGAAGTAG }\end{array}$ & 82 \\
\hline ATM related & ATR & $\begin{array}{l}\text { For: TTCACCACAGGCACAATCAC } \\
\text { Rev: TAGCCCGGATTACTTCATGG }\end{array}$ & 125 \\
\hline $\begin{array}{l}\text { ATP-dependent DNA } \\
\text { helicase II }\end{array}$ & Xrcc5/Ku80 & $\begin{array}{l}\text { For: CGTGGATGTATGGGGAATCT } \\
\text { Rev: CCTGCTGGGAATTTCTTGAG }\end{array}$ & 117 \\
\hline $\begin{array}{l}\text { ATP-dependent DNA } \\
\text { helicase II, } 70 \mathrm{kDa} \text { subunit }\end{array}$ & Xrcc6/Ku70 & $\begin{array}{l}\text { For: TGAAGACCCACATCAGCAAG } \\
\text { Rev: TGCTTCTTCAGCCCACTCTT }\end{array}$ & 100 \\
\hline Artemis & DCLRE1C & $\begin{array}{l}\text { For: CTTGAGCCCAGGAGATTGAG } \\
\text { Rev: TCCTGCGTAGCTGGGATTAC }\end{array}$ & 140 \\
\hline Beta-actin & $\beta$-Actin & $\begin{array}{l}\text { For: TTCCTGGGCATGGAGTC } \\
\text { Rev: CAGGTCTTTGCGGATGTC }\end{array}$ & 84 \\
\hline Breast cancer susceptibility 1 & $B R C A 1$ & $\begin{array}{l}\text { For: AGAGCGTCCCCTCACAAATA } \\
\text { Rev: CCGTTTGGTTAGTTCCCTGA }\end{array}$ & 137 \\
\hline Breast cancer susceptibility 2 & $B R C A 2$ & $\begin{array}{l}\text { For: AAGCCCTTTGAGAGTGGAAG } \\
\text { Rev: TCCATCTGGGCTCCATTTAG }\end{array}$ & 107 \\
\hline Checkpoint kinase 1 & Chk1 & $\begin{array}{l}\text { For: AGTGGAGGAGAGCTTTTTGAC } \\
\text { Rev: TGCAGATAAACCACCCCTGCC }\end{array}$ & 104 \\
\hline Checkpoint kinase 2 & Chk2 & $\begin{array}{l}\text { For: AGGGAAAGGAAAACGCCGTCC } \\
\text { Rev: GCTTTACCTCTCCACAGGCAC }\end{array}$ & 182 \\
\hline $\begin{array}{l}\text { Histone family } \mathrm{H} 2 \mathrm{~A} \text {, } \\
\text { member } \mathrm{X}\end{array}$ & H2AFX & $\begin{array}{l}\text { For: CTTAGCCCAGGACTTTCAGA } \\
\text { Rev: AAGATGGAGGGAGAGCTGAT }\end{array}$ & 132 \\
\hline $\begin{array}{l}\text { Mediator of DNA damage } \\
\text { checkpoint } 1\end{array}$ & $M D C 1$ & $\begin{array}{l}\text { For: ACCCCTGAATTCCAATCTCC } \\
\text { Rev: TTTAGGTTCCAAGGGTGCAG }\end{array}$ & 159 \\
\hline Meiotic recombination 11 & MRE11 & $\begin{array}{l}\text { For: TGCTTCTGCCTTTAGTGCTG } \\
\text { Rev: GCCTCTTCCTTTGTTGGTTG }\end{array}$ & 106 \\
\hline Nibrin & $N B N$ & $\begin{array}{l}\text { For: CTTCCAAGTTCTGGCTGCTT } \\
\text { Rev: GCTCACCCAАTTTCTGTTCC }\end{array}$ & 113 \\
\hline Rad50 homolog & Rad50 & $\begin{array}{l}\text { For: ACTGGCTTCACCATCAATCC } \\
\text { Rev: TGGCATCTGAAGAGCAAATG }\end{array}$ & 150 \\
\hline Rad51 homolog & Rad51 & $\begin{array}{l}\text { For: CATACGCTAGCTGTCACCTGCC } \\
\text { Rev: ACCATACCTCTCAGCCACTGCC }\end{array}$ & 126 \\
\hline Rad52 homolog & Rad52 & $\begin{array}{l}\text { For: AGGCTCAGGCCACATAATTG } \\
\text { Rev: TGACGTTCATTCTCCAGCAG }\end{array}$ & 97 \\
\hline Rad54 homolog & Rad54 & $\begin{array}{l}\text { For: AAGAGGGCCAAACACTGATG } \\
\text { Rev: AAACATTTCCTGGCAACCTG }\end{array}$ & 148 \\
\hline Replication protein A & $R P A$ & $\begin{array}{l}\text { For: GTGGCGATCTAGCTTTCAGC } \\
\text { Rev: TCAGGCCTCTTCACTGTGTG }\end{array}$ & 102 \\
\hline $\begin{array}{l}\text { Telomerase reverse } \\
\text { transcriptase }\end{array}$ & TERT & $\begin{array}{l}\text { For: GGAGCAAGTTGCAAAGCATTG } \\
\text { Rev: TCCCACGACGTAGTCCATGTT }\end{array}$ & 182 \\
\hline $\begin{array}{l}\text { X-ray repair cross } \\
\text { complementing protein } 2\end{array}$ & Xrcc2 & $\begin{array}{l}\text { For: AAGCCTCGAGCTCATCAGAA } \\
\text { Rev: ATCCTGTGCTTCACCAGTTG }\end{array}$ & 115 \\
\hline $\begin{array}{l}\text { X-ray repair cross } \\
\text { complementing protein } 3\end{array}$ & Хrcc3 & $\begin{array}{l}\text { For: CTCCCACAGGCTTTGAATTG } \\
\text { Rev: ATTCTGGGATTCAGGTCCAG }\end{array}$ & 137 \\
\hline $\begin{array}{l}\text { X-ray repair cross } \\
\text { complementing protein } 4\end{array}$ & Xrcc4 & $\begin{array}{l}\text { For: GAAGGGGAAACTGCAATCTG } \\
\text { Rev: AAGCCAACCCAGAGAGATCA }\end{array}$ & 138 \\
\hline
\end{tabular}




\section{ELISA}

Cells were grown to confluence in six-well plates. The medium was then changed to serum-free medium for $24 \mathrm{~h}$, and the cells were washed with PBS, $\mathrm{pH} 7.4$, before preparation of cell lysate in $25 \mathrm{mM}$ Tris- $\mathrm{HCl}, \mathrm{pH}$ 7.4. The amount of hGH produced and secreted over a $24 \mathrm{~h}$ period into $2 \mathrm{ml}$ serumfree medium was also estimated. ELISA for the quantification of hGH in cell lysates or secreted into the medium was performed according to the manufacturer's instructions. The protein concentration of cell lysates was determined using a Bradford protein assay.

\section{IR treatment}

IR treatment was conducted using a cobalt-60 source from an Eldorado $G$ unit (FMHS, University of Auckland) at a dose rate of $0.5 \mathrm{~Gy} / \mathrm{min}$.

\section{Total cell number assay}

Cells $\left(5 \times 10^{4}\right.$ to $\left.10 \times 10^{4}\right)$ were seeded into six-well plates in full serum media. Following treatment with IR ( 0 or 4 Gy), cells were trypsinised with $0.5 \%$ trypsin and the cell number determined using a haemocytometer every 2 days for 8-10 days.

\section{MTT assay}

Cells were plated at different concentrations (MDAvec/MDA-hGH: 1000 or 3000 cells/well; T47D-vec/ T47D-hGH: 1500 or 4000 cells/well; RL95-vec/RL95hGH and RL95-2 wild-type cells 3000 or 5000 cells/well) and irradiated $24 \mathrm{~h}$ later. The 3-(4,5dimethylthiazol-2-yl)-2,5-diphenyltetrazolium bromide (MTT) assay was conducted on days 5 and 10 as described previously (van de Loosdrecht et al. 1994).

\section{Apoptosis assay}

Apoptotic cell death was measured by fluorescent microscopic analysis of cell DNA staining patterns with Hoechst 33258 as described (Kaulsay et al. 2001). Cells were plated at $2 \times 10^{5}$ cells/well, changed into SF media and exposed to 4 Gy IR. Twenty-four and $48 \mathrm{~h}$ after radiation treatment, the cells were fixed, permeabilised and stained as described previously (Kaulsay et al. 2001). For B2036 studies, RL95-2 cells were treated with BSA or B2036 in serum-free media for $24 \mathrm{~h}$ before radiation treatment.

\section{Cell survival clonogenic assay}

Exponentially growing T47D-vec, T47D-hGH, MDAvec and MDA-hGH cells were irradiated with 4 Gy IR. Twenty-four hour post-irradiation cells were trypsinised, plated in six-well plates in triplicates at 400 cells/well and cultured in $10 \%$ serum media for 14 days. For functional hGH antagonism, cells were pretreated with $1000 \mathrm{nM} \mathrm{B2036}$ for $24 \mathrm{~h}$ before irradiation. Media containing B2036 or BSA (control) were replaced every 2 days. For antagonism of c-Src and JAK2, cells were treated with vehicle, PP1 $(20 \mu \mathrm{M})$, PP2 $(20 \mu \mathrm{M})$, PP3 $(20 \mu \mathrm{M})$ or AG490 $(50 \mu \mathrm{M})$ for $24 \mathrm{~h}$ before radiation exposure. After $24 \mathrm{~h}$, cells were trypsinised, re-plated at 400 cells/well and cultured for 14 days in full serum media. Colonies were stained with crystal violet and counted. A colony was defined as a cluster of at least 50 cells.

\section{D Matrigel assay}

Cell growth in the basement membrane extract, Matrigel, was assayed as described previously (Amiry et al. 2009). Briefly, RL95-2, T47D and MDA-MB-435S cells were suspended in $4 \%$ growth factor reduced Matrigel (BD Biosciences, San Jose, CA, USA) in 5\% serum media in 96-well plates at 1000 cells/well. On day 4, cells were pretreated with $1000 \mathrm{nM}$ B2036 or BSA, where indicated, for $24 \mathrm{~h}$ followed by 4 Gy IR. Media containing B2036 and BSA were replaced every 2 days. Cell viability was determined using Wst-1 (Roche) on day 9.

\section{Neutral comet assay}

A neutral comet assay was performed as described previously (Olive \& Banath 2006). Briefly, irradiated cells were embedded in low melting temperature Seaplaque Agarose (Cambrex Bio Science, Rockland, ME, USA) on GelBond film (Lonza Rockland, Inc., Rockland, ME, USA). The cells were lysed overnight at $37{ }^{\circ} \mathrm{C}$ in neutral lysis solution $(2 \%$ sarkosyl, $0.5 \mathrm{M}$ $\mathrm{Na}_{2}$ EDTA and $0.5 \mathrm{mg} / \mathrm{ml}$ proteinase $\mathrm{K}, \mathrm{pH}$ 8.0) and then washed in rinse buffer $(90 \mathrm{mM}$ Tris buffer, $90 \mathrm{mM}$ boric acid and $2 \mathrm{mM} \mathrm{Na} \mathrm{NDDTA}_{2}$, pH 8.5) three times. Slides were subjected to electrophoresis in $1 \times \mathrm{TBE}$ for $25 \mathrm{~min}$ at $20 \mathrm{~V}$. Comets were stained with $10 \mu \mathrm{g} / \mathrm{ml}$ propidium iodide for $20 \mathrm{~min}$ and rinsed in $400 \mathrm{ml}$ distilled water to remove excess stain. At least 100 comet images from each slide were examined. Comet tail length and tail moment were analysed using Tritek CometScore software (Version 1.5; TriTek Corp., Sumerduck, VA, USA). 


\section{$\gamma \mathrm{H} 2 \mathrm{AX}$ flow cytometry assay}

Flow cytometry was performed as described previously (MacPhail et al. 2003, Tanaka et al. 2006). Briefly, cells were seeded at $80 \%$ confluence in $10 \mathrm{~cm}$ plates in $10 \%$ serum media. After $24 \mathrm{~h}$, cells were treated with IR (4 Gy). Following treatment, cells were harvested by trypsinisation at designated time points and fixed with $80 \%$ ethanol in PBS. Sample preparation entailed rehydration of cells in PST (4\% FBS and $0.1 \%$ Triton-X-100 in PBS) for $10 \mathrm{~min}$. Samples were then centrifuged $(180 \mathrm{~g}, 5 \mathrm{~min})$, resuspended in PST containing rabbit anti-phospho-Ser139-H2AX primary antibody (1:500; Sigma-Aldrich) and incubated at $4{ }^{\circ} \mathrm{C}$ overnight with gentle agitation. Samples were washed in cold PBS containing 2\% FBS and resuspended in PST containing goat anti-rabbit FITC-conjugated secondary antibody (1:160; SigmaAldrich) and incubated for $2 \mathrm{~h}$ at room temperature on a rocker. Samples were washed again and resuspended in $400 \mu \mathrm{l}$ PBS containing $10 \mu \mathrm{g} / \mathrm{ml}$ propidium iodide and were analysed on an FACSAriaII flow cytometer (BD Biosciences, San Jose, CA, USA).

\section{Glutathione assay}

Total cellular glutathione levels were determined in MDA-vec, MDA-hGH, T47D-vec and T47D-hGH using a glutathione colorimetric assay kit (SigmaAldrich) as per manufacturer's instructions. Approximately $1 \times 10^{8}$ cells from each cell line were used for sample preparation. 5-Thio-2-nitrobenzoic acid was measured spectrophotometrically at $412 \mathrm{~nm}$.

\section{Xenograft analyses}

All experiments were carried out under a protocol approved by the University of Auckland Animal Ethics Committee. MDA-Vec or MDA-hGH $\left(5 \times 10^{6}\right)$ cells were suspended in $100 \mu \mathrm{l}$ Matrigel and injected subcutaneously into the right hind quarter of female Ragl immunodeficient mice. Tumour cells were inoculated subcutaneously on the dorsal midline, $1.5 \mathrm{~cm}$ from the base of the tail. Tumour volume $\left(\left(\right.\right.$ length $\times$ width $\left.\left.^{2}\right) \times 3.14 / 6\right)$ was determined with a digital calliper twice weekly. Tumour growth delay experiments were carried out with $165-180 \mathrm{~mm}^{3}$ tumours treated with IR (cobalt-60, 3 Gy/day at $0.5 \mathrm{~Gy} / \mathrm{min}$ carried out over three consecutive days starting on day 12). Unanaesthetised mice ( $n=6$ per treatment group) were restrained in jigs behind lead shielding to expose tumours to a lateral radiation beam. Tumour regrowth/regression was monitored up to day 19 .

\section{Statistical analysis}

All numerical data are expressed as mean \pm s.E.M. of triplicate determinants. Statistical significance between treatment groups was determined using an unpaired two-tailed $t$-test or a two-way ANOVA (Holm-Sidak) using SigmaPlot 11.0. All in vitro experiments were repeated at least three times. A single representative figure is shown.

\section{Results}

\section{Autocrine hGH increases mammary and endometrial carcinoma cell viability and total cell number after exposure to IR}

To determine the effect of autocrine hGH on IR-induced cell death, we used mammary carcinoma cell lines, MDA-MB-435S and T47D, stably transfected with an expression vector containing the $h G H$ gene GH1 (pcDNA3-hGH). These cell lines are designated MDA-hGH and T47D-hGH and have been described previously (Bougen et al. 2011). A second cell line transfected with an empty pcDNA3 vector was generated in parallel for control purposes (designated MDA-vec and T47D-vec respectively). Generation of stable forced expression of hGH in endometrial carcinoma cell line RL95-2, which was also used in this study, has been described previously (Pandey et al. 2008).

MDA-vec and T47D-vec cells do not produce detectable amounts of $h G H$ mRNA or protein when cultured under serum-free conditions whereas MDAhGH and T47D-hGH stable cell lines express $h G H$ mRNA as demonstrated by semiquantitative RT-PCR (Bougen et al. 2011) and secrete hGH protein into the media, as demonstrated by western blot analysis (Bougen et al. 2011) and ELISA (184 ng/ml hGH $(8.35 \mathrm{nM})$ secreted by MDA-hGH cells and $390 \mathrm{ng} / \mathrm{ml}$ $(17.68 \mathrm{nM}) \mathrm{hGH}$ secreted by T47D-hGH cells over $24 \mathrm{~h}$ ) (data not shown). Our previous study demonstrated that wild-type RL95-2 cells express endogenous $h G H$ mRNA and protein with $0.5 \mathrm{ng} / \mathrm{ml}$ $(22.73 \mathrm{pM})$ secreted into the media over $24 \mathrm{~h}$ as demonstrated by ELISA (Pandey et al. 2008). MDAvec/MDA-hGH, T47D-vec/T47D-hGH and RL95-vec/ RL95-hGH cells also express $h G H R$ mRNA (Pandey et al. 2008, Bougen et al. 2011).

Radioresistance is characterised by enhanced tumour cell survival following exposure to IR. Due to evidence suggesting a radioprotective role for $\mathrm{GH}$ (Gomez-de-Segura et al. 1998, Vazquez et al. 1999, Mylonas et al. 2000, Isla et al. 2002, Madrid et al. 2002, Raguso et al. 2002, Lempereur et al. 2003, 
Morante et al. 2003, Tekin et al. 2006), we investigated whether autocrine hGH enhanced mammary and endometrial cancer cell viability following treatment with IR. Three pairs of stably transfected cell lines (MDA-vec and MDA-hGH, T47D-vec and T47D-hGH and RL95-vec and RL95-hGH cells) were exposed to an initial treatment range of 0-8 Gy IR. Autocrine hGH significantly enhanced cell viability of MDA-MB435S, T47D and RL95-2 cells at all doses of radiation tested (Fig. 1A, D and G). Following treatment with 2 Gy IR, autocrine hGH increased MDA-MB-435S cell viability by 1.5 -fold, T47D cell viability by 1.5 -fold and RL95-2 cell viability by 1.4 -fold over 10 days $(P<0.001)$. At $4 \mathrm{~Gy} \mathrm{IR}$, autocrine hGH increased MDA-MB-435S cell viability by 1.6 -fold (Fig. 1A),
T47D cell viability by 1.9 -fold (Fig. 1D) and RL95-2 cell viability by 2.9 -fold (Fig. 1G) over 10 days $(P<0.001)$.

Total cell number was determined over 7 days in serum-replete (10\% FBS) conditions following treatment with 4 Gy IR. Exposure to IR significantly reduced increases in total cell number in all cell lines over 7 days (Fig. 1B, C, E, F, H and I). In addition, MDA-hGH cells exhibited significantly higher cell number at day 7 following radiation treatment compared with the MDA-vec cell line when expressed as a percentage of untreated controls (MDA-hGH $38.96 \pm 3.10 \%$ vs MDA-vec $26.12 \pm 2.75 \% ; P<0.05)$. A similar trend was observed in T47D-hGH (T47DhGH $46.91 \pm 3.18 \%$ vs T47D-vec $26.30 \pm 0.84 \%$;
A

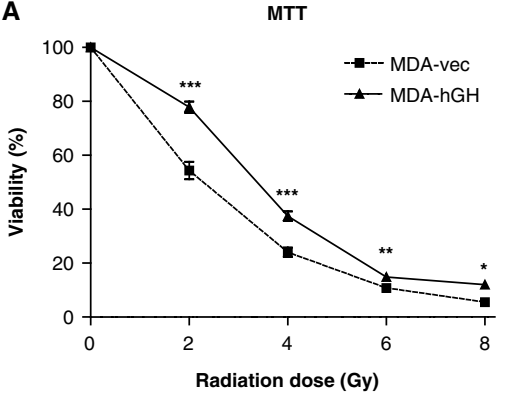

D

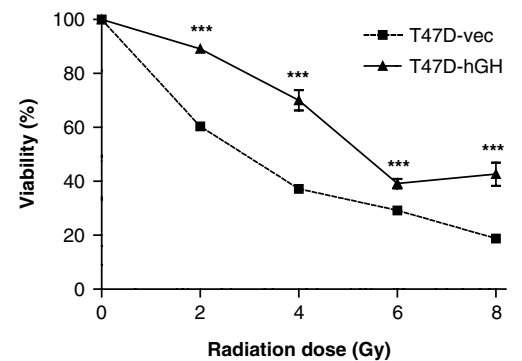

G

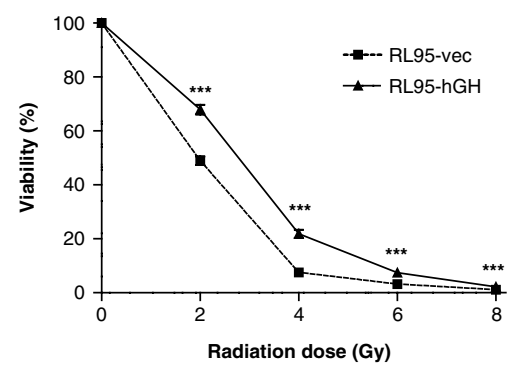

B

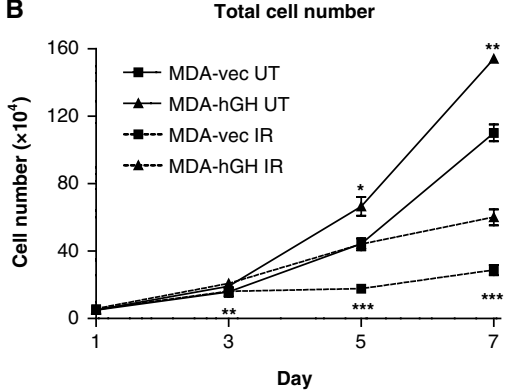

E

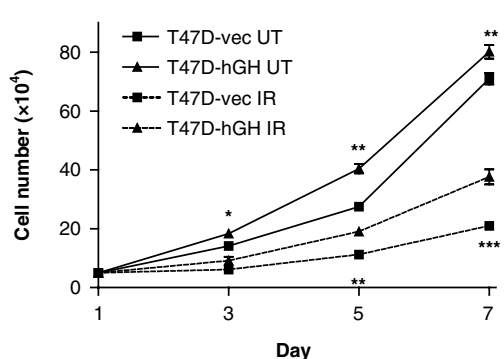

H

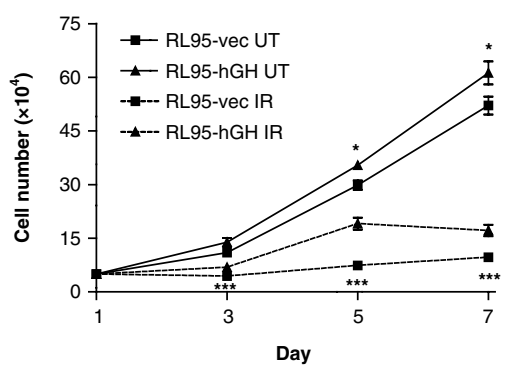

C

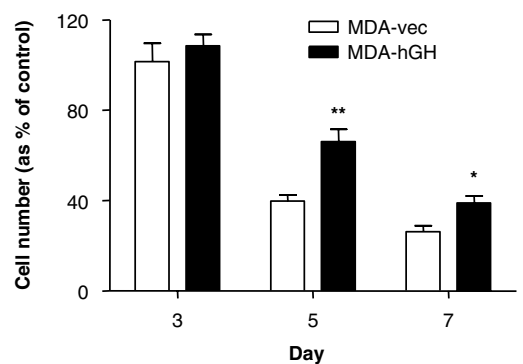

$\mathbf{F}$

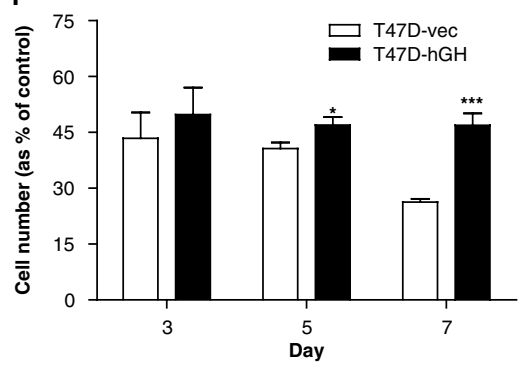

1

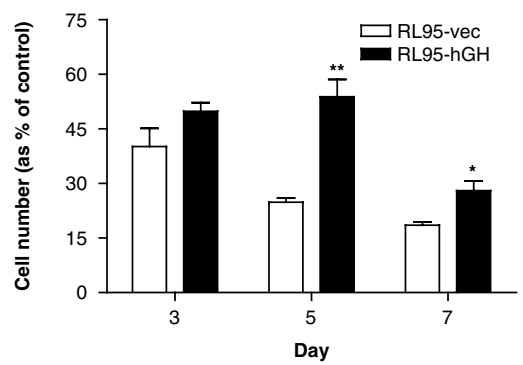

Figure 1 Autocrine hGH increases cell viability and total cell number following treatment with ionising radiation. (A, D, F) MTT viability assay. Cells were exposed to IR doses of 0-8 Gy, cultured in serum-replete medium (10\% FBS) and analysed on day 10 . $(B, E, H)$ Total cell number assay conducted in serum-replete medium after exposure to $4 \mathrm{~Gy} \mathrm{IR}$. (C, F, I) Total cell number assay results presented as percent of untreated control on the indicated days. (A, B, C) MDA-vec and MDA-hGH cell lines. (D, E, F) T47D-vec and T47D-hGH cell lines. (G, H, I) RL95-vec and RI95-hGH cell lines. Cells were plated at 5000 cells/well $\left({ }^{\star} P<0.05,{ }^{\star \star} P<0.001,{ }^{\star \star \star} P<0.0001\right)$. Experiments were repeated at least three times. A single representative figure is shown. 
$P<0.001)$ and RL95-hGH (RL95-hGH $28.04 \pm 2.6 \%$ vs RL95-vec $18.55 \pm 0.850 \% ; P<0.05)$ stable cell lines compared with the respective control cell lines following treatment with IR (Fig. 1B, C, E, F, H and I).

We also determined the effect of treatment with exogenous hGH $(100 \mathrm{nM})$ on MDA-vec cell viability and MDA-vec/MDA-hGH total cell number following treatment with IR. No significant effect on MDA-vec cell viability was observed below $100 \mathrm{nM}$ hGH following treatment with 4 Gy IR (Fig. 2A). hGH $(100 \mathrm{nM})$ increased cell viability by $1.4-$ fold following exposure to 4 Gy IR and this concentration was used in subsequent assays (Fig. 2A).

A total cell number assay was conducted in which MDA-vec and MDA-hGH cells were exposed to 4 Gy IR and then treated with $100 \mathrm{nM}$ hGH or BSA as a control. Treatment with exogenous hGH increased MDA-vec total cell number by 1.5 -fold on day 9 following IR but had no significant effect on MDAhGH total cell number (Fig. 2B and C). While exogenous hGH significantly increased MDA-vec total cell number following 4 Gy radiation compared with control BSA-treated cells (1.5-fold), it was not as effective as the protection afforded by autocrine hGH (2.2-fold; MDA-vec vs MDA-hGH BSA-treated cells; Fig. 2B and C). MDA-hGH cells secrete $8.35 \mathrm{nM} \mathrm{hGH}$ into the media over a $24 \mathrm{~h}$ period. Thus, the radioprotective effect of autocrine hGH was significantly more potent than $100 \mathrm{nM}$ hGH added exogenously.

\section{Autocrine hGH reduces mammary carcinoma cell apoptotic cell death and increases clonogenic survival after exposure to IR}

Apoptotic cell death was determined in MDA-MB435S and T47D cells after IR treatment. Untreated MDA-hGH and T47D-hGH cells exhibited significantly lower apoptotic cell death after 24 and $48 \mathrm{~h}$ in serum-free media when compared with respective control cell lines, MDA-vec and T47D-vec (Fig. 3A and B). Following treatment with 4 Gy radiation, MDA-vec cells exhibited significantly higher apoptotic cell death than MDA-hGH cells at both time points (Fig. 3A). When expressed as fold difference of untreated control, autocrine hGH reduced the effect of IR on MDA-MB-435S apoptotic cell death (MDA-hGH 1.29-fold vs MDA-vec 1.57-fold at $24 \mathrm{~h}$ (two-way ANOVA; $P<0.05$ ) and 1.7 - vs 1.75 -fold at $48 \mathrm{~h}$ (two-way ANOVA; $P<0.05$ )). A more striking effect was observed with T47D cells; as with MDA-MB-435S, T47D-vec cells exhibited significantly higher apoptotic cell death than T47D-hGH cells at both time points (Fig. 3B). When expressed as fold difference of untreated control, autocrine hGH reduced the effect of IR on T47D apoptotic cell death (T47D-hGH 1.38-fold vs T47D-vec 1.57 -fold at $24 \mathrm{~h}$ (two-way ANOVA; $P<0.01$ ) and 1.88 - vs 2.33 -fold at
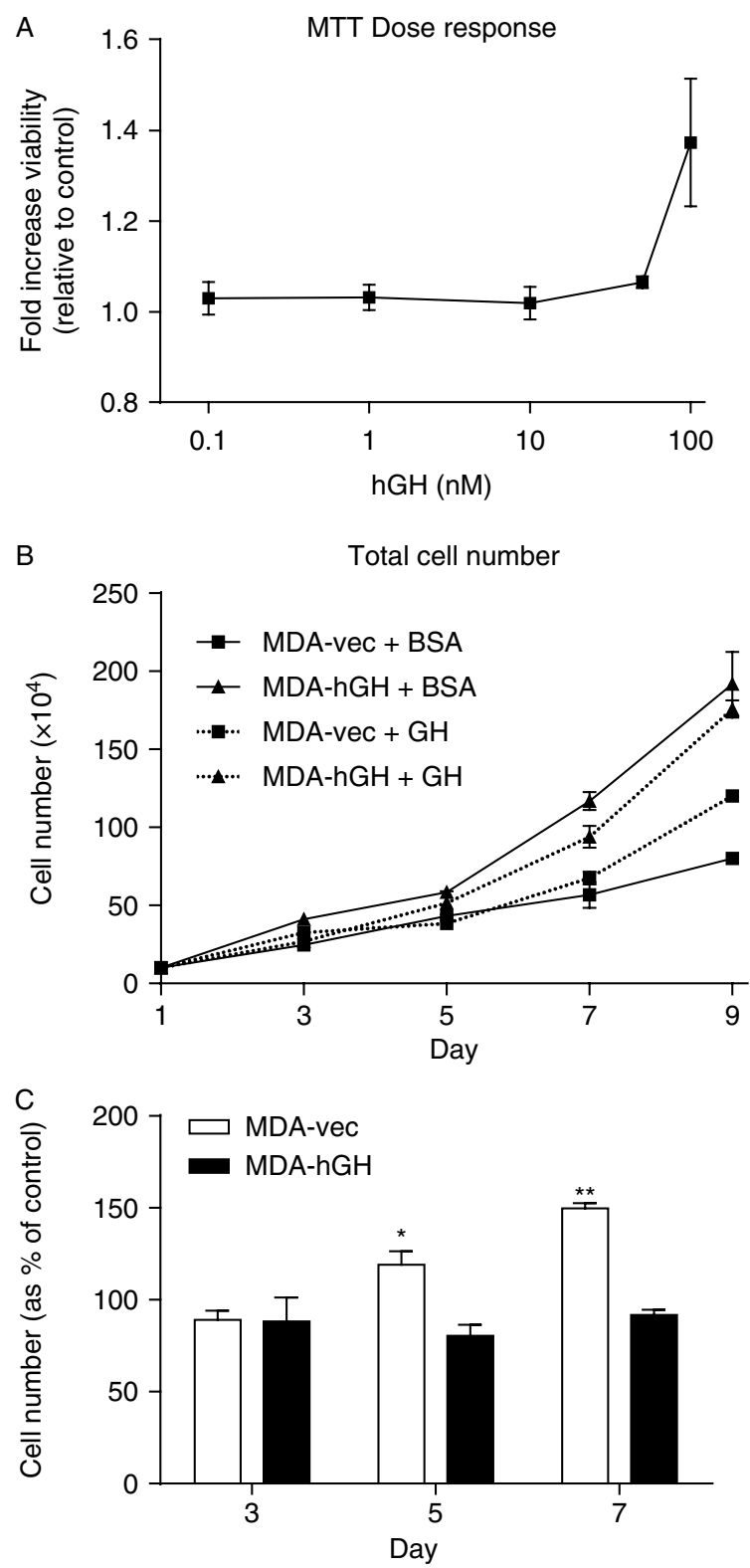

Figure 2 The effect of exogenous hGH on mammary carcinoma cell radiation sensitivity $(A)$ MTT viability assay. MDA-vec cells were exposed to 4 Gy IR and treated with $100 \mathrm{nM} \mathrm{hGH}$ or BSA (control) to determine the effect of exogenously added hGH on radiosensitivity. No significant effect on MDA-vec cell viability was observed below $100 \mathrm{nM} \mathrm{hGH}$. (B) Total cell number assay conducted in serum-replete medium after exposure to 4 Gy IR. Cells were plated at 10000 cells/well. Following exposure, cells were treated with $100 \mathrm{nM} \mathrm{hGH}$ or BSA (control) for 9 days.

(C) Total cell number assay results presented as per cent of untreated control $\left({ }^{\star} P<0.05,{ }^{\star *} P<0.001\right)$. 
48 h (two-way ANOVA; $P<0.01$ )). Thus, autocrine hGH protects MDA-MB-435S and T47D cells from IR-induced apoptotic cell death.

A clonogenic survival assay was used to measure the ability of MDA-vec and MDA-hGH cells to form colonies after treatment with IR. Untreated MDA-hGH cells exhibited a 1.7-fold higher plating efficiency (PE) compared with MDA-vec cells $(P<0.001)$. This effect was enhanced following $4 \mathrm{~Gy}$ radiation treatment where MDA-hGH cells exhibited a 2.8-fold higher PE compared with MDA-vec cells $(P<0.001$; Fig. 4A). Over repeat experiments, autocrine hGH increased overall clonogenic survival by 1.4-fold in MDA-hGH compared with MDA-vec cells following IR treatment $(P<0.05 ; n=6)$. IR exposure reduced MDA-vec cell clonogenic survival by 1.7 -fold, whereas radiation exposure was less effective in reducing MDA-hGH clonogenic survival, reducing it by 1.3 -fold $(P<0.05$; $n=6)$. Thus, MDA-hGH cells were significantly more resistant to IR-induced cell death than the control cell line in the clonogenic survival assay.

Clonogenic assays were also conducted with T47Dvec and T47D-hGH cells. Untreated T47D-hGH cells exhibited a 1.7-fold higher PE than T47D-vec cells $(P<0.001)$, and following 4 Gy treatment, T47D-hGH cells exhibited a fourfold higher PE than T47D-vec cells $(P<0.001$; Fig. 4B). Over repeat experiments, autocrine hGH increased relative clonogenic survival following IR treatment by 1.5 -fold in T47D-hGH compared with T47D-vec cells following IR treatment $(P<0.05 ; n=3)$. IR exposure reduced T47D-vec clonogenic survival by 2.1 -fold, whereas radiation exposure was less effective in reducing T47D-hGH clonogenic survival, reducing it by 1.3 -fold $(P<0.05$; $n=3)$. Thus, T47D-hGH cells were significantly more resistant to IR-induced cell death than the control cell line in the clonogenic survival assay.

Autocrine hGH significantly enhanced MDA-MB435S and T47D cell growth in the extracellular matrix extract Matrigel after exposure to IR (Figs 4C and 3D). Untreated MDA-hGH cells exhibited a 1.3-fold higher cell viability in Matrigel than MDA-vec cells $(P<0.05)$, and following 4 Gy treatment, MDA-hGH cells exhibited a 1.6-fold higher cell viability than MDA-vec cells $(P<0.05$; Fig. 4C). IR exposure reduced MDA-vec cell growth in Matrigel by 1.4-fold, whereas radiation exposure reduced MDAhGH cell growth by 1.2-fold; however, this reduction was not significant by two-way ANOVA. Untreated T47D-hGH cells exhibited a 1.4-fold higher cell viability in Matrigel than T47D-vec cells $(P<0.01)$ and following $4 \mathrm{~Gy}$ treatment T47D-hGH cells exhibited a 1.8-fold higher cell viability than T47D-vec cells $(P<0.001$; Fig. 4D). IR exposure reduced T47D-vec cell growth in Matrigel by 1.7-fold, whereas radiation exposure reduced T47D-hGH cell growth by 1.3-fold $(P<0.5$; two-way ANOVA).

\section{The effect of autocrine hGH on sensitivity to IR in vivo}

Xenograft studies were conducted to determine whether autocrine $\mathrm{hGH}$ protected mammary carcinoma cells against IR-induced damage in vivo. MDA-vec and MDA-hGH cells were inoculated subcutaneously into female Ragl immunodeficient mice. Tumours were treated with IR over three consecutive days starting on day 12 and tumour regrowth/regression was monitored on days 15 and 19. Both MDA-vec and MDA-hGH tumour volumes reduced following treatment with radiation; however, MDA-vec tumour volume
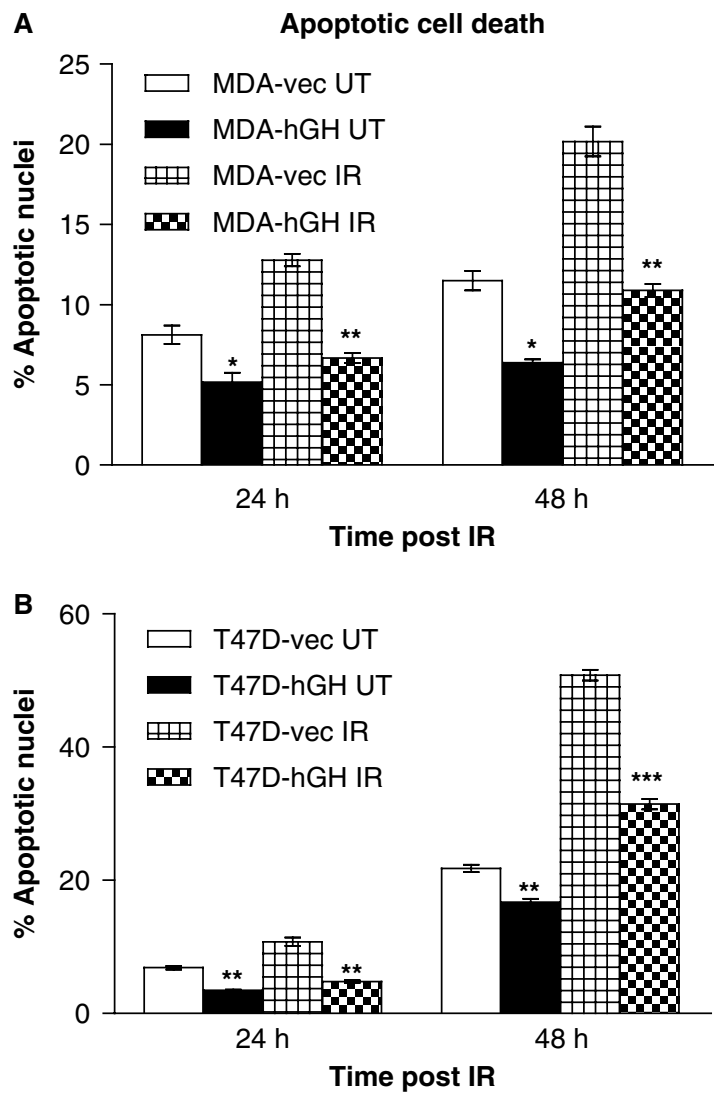

Figure 3 Autocrine hGH reduces apoptotic cell death following treatment with ionising radiation. (A) MDA-vec and MDA-hGH and (B) T47D-vec and T47D-hGH cells were cultured in serumfree RPMI and left untreated or exposed to 4 Gy IR. Apoptotic nuclei were counted at 24 and $48 \mathrm{~h}\left({ }^{\star} P<0.05\right.$, ${ }^{\star \star} P<0.001$,

$\left.{ }^{\star * \star} P<0.0001\right)$. Experiments were repeated at least three times. A single representative figure is shown. 

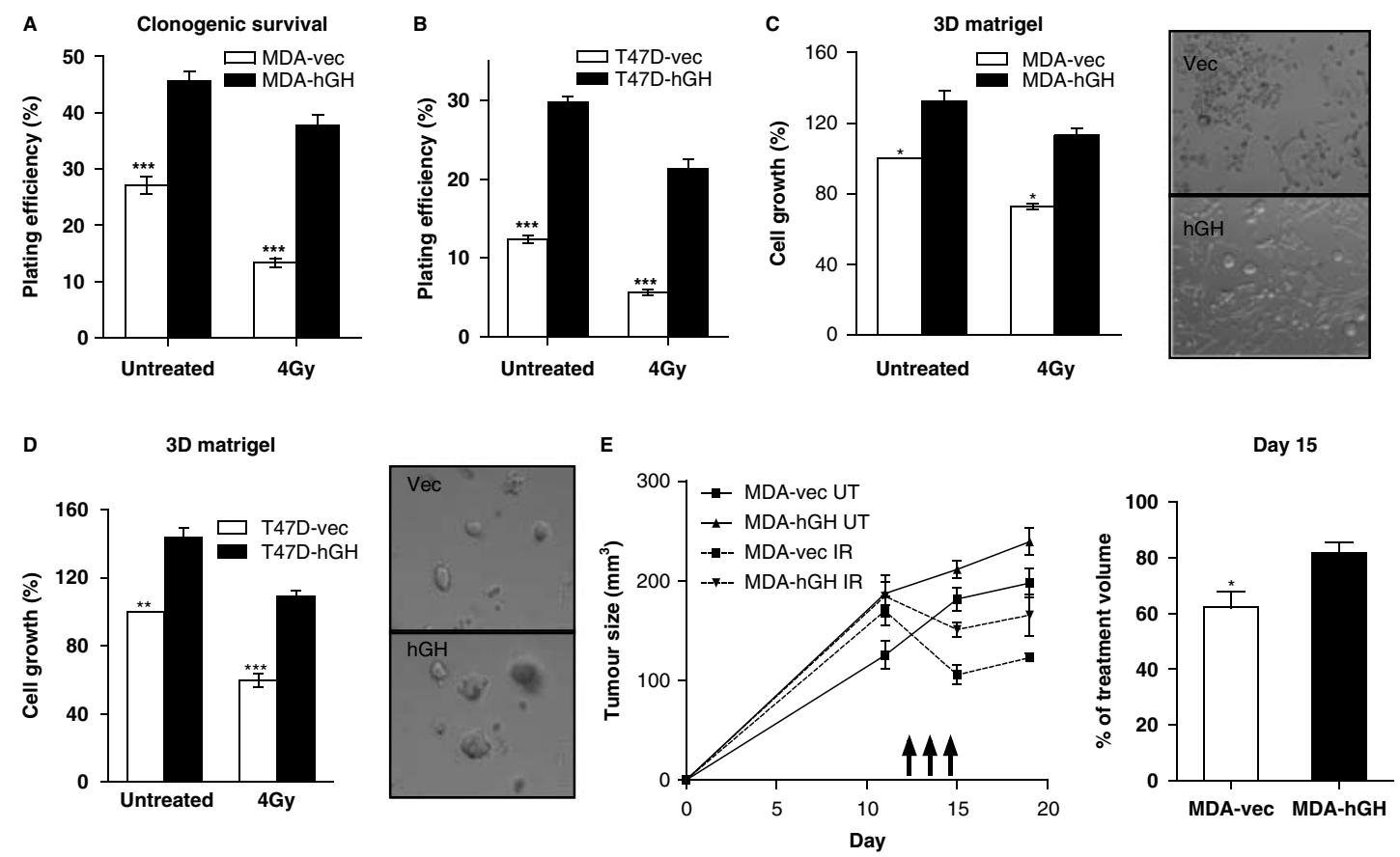

Figure 4 Autocrine hGH enhances clonogenic survival and growth in Matrigel following treatment with ionising radiation. (A and $B$ ) Clonogenic assay. Untreated or 4 Gy radiation-treated MDA-MB-435S (A) or T47D (B) cell lines were plated at 400 cells/well and cultured for 14 days in serum-replete media. Colonies with $>50$ cells were counted and the plating efficiencies (PE) calculated. $\mathrm{PE}=$ (number of colonies formed/number of cells seeded) $\times 100 \% .\left({ }^{\star} P<0.05,{ }^{\star \star} P<0.001,{ }^{\star \star \star} P<0.0001\right)$. (C and D) 3D Matrigel assay. MDA-MB-435S (C) or T47D (D) cells were treated with 4 Gy IR and cultured in growth factor reduced Matrigel for 9 days. Cell viability was determined using Wst-1. All in vitro experiments were repeated at least three times. A single representative figure is shown. (E) Xenograft analysis. Rag1 immunodeficient mice were implanted with MDA-vec or MDA-hGH cells. Tumours were left untreated or subjected to fractionated IR treatment starting on day 11 post implantation and tumour volume measured on days 15 and 17.

decreased more significantly than MDA-hGH tumours (Fig. 4E). IR treatment resulted in a $37.79 \%$ decrease in the treatment volume for MDA-vec tumours on day 15 , whereas MDA-hGH tumour volume decreased by $18.37 \%(P<0.05$; two-way ANOVA; Fig. 4E).

\section{Enhanced clonogenic survival afforded by auto- crine hGH is mediated by JAK2 and Src kinases}

Both JAK2 and c-Src are concomitantly activated following binding of hGH to its receptor (Ling et al. 2003). To determine the relative contribution of JAK2 and c-Src to the autocrine hGH-stimulated increase in survival following IR, we conducted clonogenic survival assays in mammary carcinoma cells treated with pharmacological inhibitors of JAK2 (AG490) or Src kinases (PP1 and PP2). We also used the inactive structural analogue PP3 as a control in the experiments. Figure 5 demonstrates that the increased clonogenic survival afforded by autocrine hGH following IR is partially abrogated in both T47D-hGH and MDA-hGH cell lines following treatment with AG490, PP1 and PP2, but unaffected in the presence of the inactive analogue PP3. PP1, PP2 and AG490 decreased both the basal (MDA-vec) and the autocrine hGH-stimulated increase in clonogenic survival in the MDA-MB-435S cell line (Fig. 5A), while only AG490 affected basal clonogenic survival in T47D cells (Fig. 5B). Thus, the protective effect of autocrine hGH against IR-induced cell death is mediated by both JAK2 and the c-Src family of proteins in these cell lines (Fig. 5A and B).

\section{Autocrine hGH protects mammary carcinoma cells against IR-induced DNA damage}

In order to assess whether autocrine hGH affected the induction of DNA damage following IR exposure in MDA-MB-435S and T47D cells, a neutral comet assay was performed. The neutral comet assay detects DNA DSBs, which are the principle cytotoxic lesion caused by IR. Neutral comet analysis indicated that endogenous levels of DSBs in untreated MDA-vec and MDAhGH cells were similar (Fig. 6A). However, at 4 Gy IR treatment, MDA-hGH exhibited significantly reduced radiation-induced DNA damage, as measured by the tail moment (defined as the product of the tail 
A
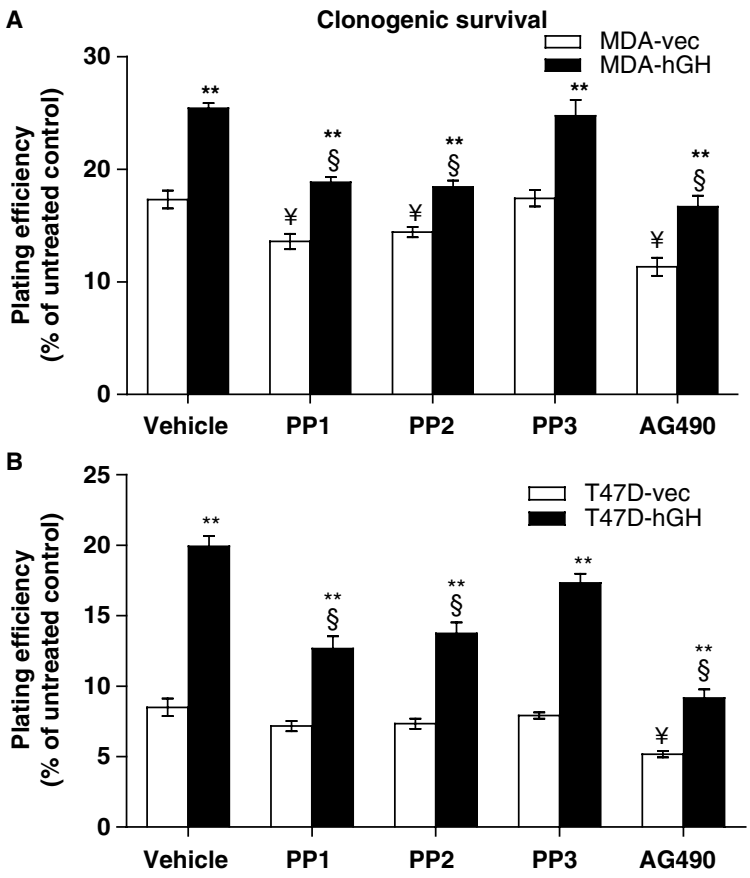

Figure 5 The protective effect of autocrine hGH against IR-induced cell death is mediated by both JAK2 and the c-Src family of proteins in MDA-MB-435S and T47D cells. (A) T47D and (B) MDA-MB-435S. Cells were treated with vehicle, PP1 $(20 \mu \mathrm{M})$, PP2 $(20 \mu \mathrm{M})$, PP3 $(20 \mu \mathrm{M})$ or AG490 $(50 \mu \mathrm{M})$ for $24 \mathrm{~h}$ before radiation exposure. After $24 \mathrm{~h}$, irradiated cells were trypsinised and plated in six-well plates at 400 cells/well for 14 days. The data are represented as plating efficiency (PE) following IR treatment expressed as a percentage of the untreated control PE. Asterisks $\left({ }^{* *}\right)$ indicates the changes observed in hGH-transfected cells are statistically significant compared with the control cell line (vec) $(P<0.01)$, whereas $¥$ indicates changes after treatments observed between control (vec) cells are significant $(P<0.05)$ and $\S$ indicates changes after treatments observed between hGH transfected cells are significant $(P<0.001)$ when compared to vehicle treated cells. Experiments were repeated at least three times. A single representative figure is shown.

length and the fraction of total DNA in the tail; Fig. 6A), and by the percentage of DNA measured in the tail of comets (data not shown). Autocrine hGH prevented induction of DNA DSBs in MDA-hGH cells after treatment with 4 Gy IR, whereas IR induced a 1.7-fold increase in DNA DSB damage in MDA-vec cells at $4 \mathrm{~Gy}$ (Fig. 6A). When the IR dose was increased to $8 \mathrm{~Gy}$, DNA damage was observed in both cell lines (Fig. 6A); however, at $8 \mathrm{~Gy}$, the DNA damage induced in MDA-hGH cells was significantly reduced compared with MDA-vec cells. We also investigated DNA damage in T47D-vec and T47DhGH cells following IR exposure. IR (4 Gy) induced DNA damage in both T47D-vec and T47D-hGH cell lines (Fig. 6C). However, DNA damage induced in
T47D-hGH cells was significantly reduced compared with T47D-vec cells following $4 \mathrm{~Gy}$ radiation as demonstrated by the tail moment.

DNA damage was also assessed by flow cytometry with cells immunofluorescently labelled with an antibody against phosphorylated histone H2AX (phospho-H2AX). H2AX is rapidly phosphorylated on serine 139 in response to DNA DSB damage (Rogakou et al. 1998). Phospho-H2AX plays a key role in the recruitment of DNA repair sensing and repair proteins after exposure to genotoxic agents such as IR (Paull et al. 2000, Celeste et al. 2002, Stiff et al. 2004). The level of phospho-H2AX in the control cell line (MDA-vec), as determined by flow cytometry, increased substantially after treatment with 4 Gy radiation with maximum phosphorylation observed at $3 \mathrm{~h}$ post treatment (Fig. $6 \mathrm{D}$ and $\mathrm{F}$ ). In contrast, phosphoH2AX levels in MDA-hGH cells increased only slightly immediately after radiation treatment and returned to untreated levels within $3 \mathrm{~h}$ of treatment (Fig. 6E and F). Thus, autocrine hGH reduced levels of IR-induced DNA damage in the MDA-MB-435S cell line.

The reducing ability of intracellular sulphhydryl compounds such as glutathione has been implicated in determining cellular radiosensitivity (Estrela et al. 2006). As we have previously demonstrated that autocrine hGH increases mRNA expression of glutathione peroxidase $(G P X)$, which catalyses the oxidation of glutathione, and glutamylcysteine synthetase $(G C S)$, an enzyme involved in glutathione biosynthesis, in MCF-7 cells (Zhu et al. 2005b), we investigated whether autocrine hGH altered the intracellular levels of glutathione in MDA-MB-435S and T47D cells using a glutathione assay. However, no significant difference in total glutathione concentration was observed in MDA-vec vs MDA-hGH or T47D-vec vs T47D-hGH cell lines (data not shown).

Real-time PCR was conducted to determine mRNA levels of selected genes implicated in DNA repair, the cellular response to DNA damage and radioresistance. Expression levels of the majority of genes examined by real-time PCR were not affected by autocrine hGH. However, autocrine hGH increased mRNA levels of the breast cancer susceptibility gene, BRCA2, and the DNA repair protein involved in homologous recombination, X-ray repair cross complementing group-2 (XRCC2), in MDA-hGH cells compared with MDA-vec cells (Table 2). Consistent with our previous observations in MCF-7 cells (Emerald et al. 2007), autocrine hGH also increased mRNA levels of TERT, the catalytic subunit of telomerase in MDA-MB-435S cells (Table 2). 
A

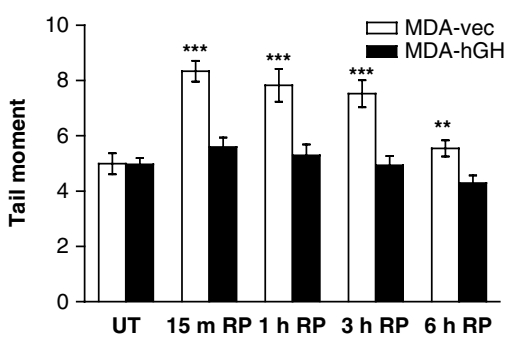

D

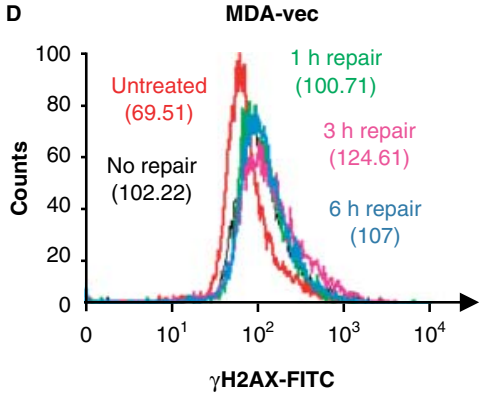

B

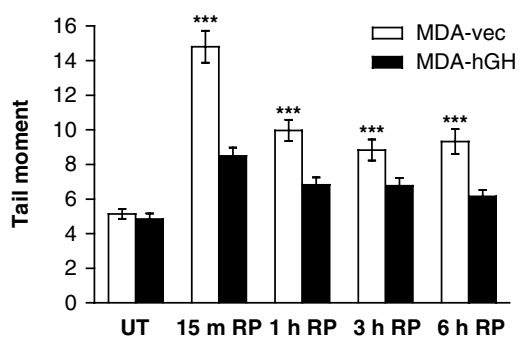

E

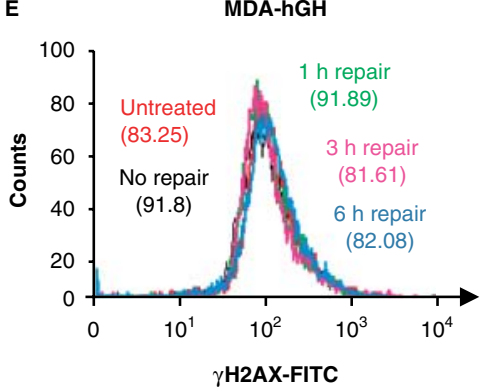

C

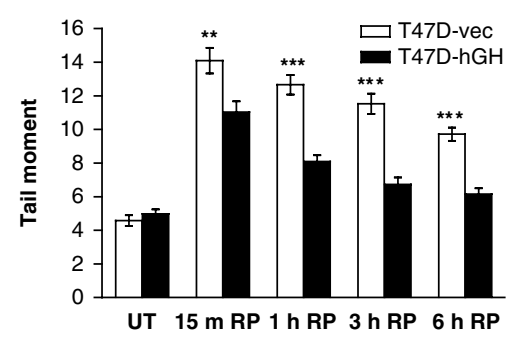

F

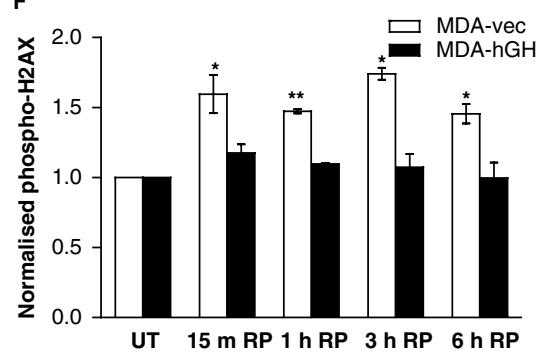

Figure 6 Autocrine hGH enhances DNA repair in mammary carcinoma cells. (A and B) Neutral comet assay. MDA-vec and MDA-hGH cells were treated with (A) 4 Gy or (B) 8 Gy IR and DNA double-stranded breaks were measured using the neutral comet assay. The tail moment correlates with the level of DSBs present in untreated (UT) cells, cells at $15 \mathrm{~m}$ repair time (15 m RP), cells at $1 \mathrm{~h}$ repair $(1 \mathrm{~h} \mathrm{RP}), 3 \mathrm{~h}$ repair $(3 \mathrm{~h} \mathrm{RP})$ or $6 \mathrm{~h}$ repair $(6 \mathrm{~h} \mathrm{RP})$. (C) Neutral comet assay conducted with T47D-vec and T47D-hGH cells treated with 4 Gy IR. (D and E) Phospho-H2AX flow cytometry assay. Phosphorylation of H2AX on serine 139 directly correlates with the presence of DSBs. Fluorescent histograms of cells subjected to IR followed by $0,1,3$ and $6 \mathrm{~h}$ incubation. Increasing H2AX phosphorylation is indicated by a rightward shift along $x$-axis (D) MDA-vec and (E) MDA-hGH cells (values on the graphs indicate peak geo means). (F) Bar graph representation of the average phospho-H2AX fluorescent histogram geo means from three experiments $\left({ }^{\star} P<0.05,{ }^{\star \star} P<0.001,{ }^{* \star} P<0.0001\right)$. Experiments were repeated at least three times. A single representative figure is shown.

\section{Functional antagonism of autocrine $\mathrm{hGH}$ reduces RL95-2 cell viability, total cell number, clono- genic survival and DNA damage after treatment with IR}

RL95-2 wild-type cells endogenously express and secrete hGH (Pandey et al. 2008) and hence provide a suitable system for investigating the effect of functional antagonism of hGH on post-radiation cell survival. Functional antagonism of hGH was achieved using the hGHR antagonist, B2036. B2036 is the peptide component of pegvisomant (Pfizer), which is FDA approved for the treatment of acromegaly (Kopchick et al. 2002, van der Lely \& Kopchick 2006). It consists of a mutated hGH molecule that competitively binds the receptor but does not activate signal transduction. Treatment of RL95-2 cells with B2036 over 10 days in full serum media significantly reduced RL95-2 cell viability after 4 Gy IR compared with control cells treated with BSA (Fig. 7A). A marked effect was observed at day 5: B2036-treated cells exhibited $37.8 \%$ cell survival compared with $61.7 \%$ in BSA-treated cells $(P<0.001)$. A total cell number assay performed over 7 days demonstrated that
B2036 significantly reduced RL95-2 total cell number compared with control, BSA-treated cells (Fig. 7B and C). Combined treatment with B2036 and 4 Gy IR reduced RL95-2 total cell number additively when compared with either treatment with B2036 or IR alone (Fig. 7B and C). Combined treatment with B2036 and 4 Gy IR increased apoptotic cell death additively when compared with either treatment with B2036 or IR alone (Fig. 7D). In addition, combined treatment with IR and B2036 synergistically reduced RL95-2 cell clonogenic survival $(P<0.001$; two-way ANOVA; Fig. 7E). In a 3D Matrigel assay, B2036 reduced RL95-2 cell growth in Matrigel after treatment with IR compared with BSA-treated control cells (Fig. 7F). Finally, in a neutral comet assay, B2036 significantly enhanced induction of DNA DSBs after exposure to radiation compared with BSA-treated controls (Fig. 7G). Thus, treatment with B2036 increases the sensitivity of RL95-2 cells to treatment with IR.

\section{Discussion}

Previous studies demonstrating a radioprotective effect for $\mathrm{GH}$ have investigated whether $\mathrm{GH}$ 
Table 2 Quantitative real-time PCR analysis of the effect of forced expression of hGH in MDA-MB-435S breast cancer cells on mRNA levels of several key genes functionally involved in cell cycle, DNA repair and radioresistance

\begin{tabular}{lrc}
\hline Gene symbol & Fold change & $\boldsymbol{P}$ \\
\hline NBN & 1.02 & $3.90 \times 10^{-1}$ \\
MRE11 (MRE11A) & 1.04 & $3.93 \times 10^{-1}$ \\
RAD50 & 1.19 & $1.78 \times 10^{-1}$ \\
RAD51 & 1.07 & $3.47 \times 10^{-1}$ \\
RAD52 & 1.08 & $1.22 \times 10^{-1}$ \\
$R A D 54($ ATRX) & 1.01 & $4.73 \times 10^{-1}$ \\
BRCA1 & 1.52 & $1.34 \times 10^{-1}$ \\
BRCA2 & 1.61 & $4.82 \times 10^{-2}$ \\
RPA & 1.13 & $2.77 \times 10^{-1}$ \\
H2AFX & 1.34 & $3.92 \times 10^{-2}$ \\
ATM & -1.00 & $4.90 \times 10^{-1}$ \\
XRCC4 & 1.12 & $3.49 \times 10^{-1}$ \\
XRCC2 & 1.52 & $2.91 \times 10^{-2}$ \\
XRCC3 & 1.12 & $8.61 \times 10^{-2}$ \\
ATR & 1.37 & $1.01 \times 10^{-1}$ \\
PRKDC & 1.07 & $3.05 \times 10^{-1}$ \\
LIGASE 4F & -1.19 & $1.74 \times 10^{-1}$ \\
XRCC6/KU70 & 1.06 & $3.22 \times 10^{-1}$ \\
XRCC5/KU80 & 1.01 & $4.75 \times 10^{-1}$ \\
CHK1 (CHEK1) & -1.03 & $2.15 \times 10^{-1}$ \\
CHK2 (CHEK2) & -1.20 & $2.22 \times 10^{-1}$ \\
DCLRE1C & 1.04 & $4.66 \times 10^{-1}$ \\
ABL & 1.31 & $5.75 \times 10^{-2}$ \\
MDC1 & 1.29 & $4.91 \times 10^{-2}$ \\
TERT & 2.67 & $2.09 \times 10^{-3}$ \\
\hline & &
\end{tabular}

administration reduces toxicity associated with radiation treatment in normal cells and tissues. As endogenous hGH expression is observed in a proportion of breast and endometrial tumours (Slater et al. 2006, Wu et al. 2011), we hypothesised that autocrine hGH would reduce cancer cell sensitivity to radiation-induced cell death, thus potentially reducing the effectiveness of radiotherapy. In the current study, we describe a novel role for autocrine hGH in radioresistance and protection from IR-induced DNA damage in mammary and endometrial carcinoma cell lines. Cell viability and total cell number assays demonstrated that autocrine hGH promoted MDA-MB-435S, T47D and RL95-2 cell regrowth following treatment with IR. We also observed that autocrine hGH had a protective effect against IR-induced DNA damage in vitro and tumour regression in vivo. Conversely, functional antagonism of endogenous hGH in RL95-2 cells increased the sensitivity of these cells to treatment with IR. To our knowledge, this is the first study demonstrating that hGHR antagonism enhances IR-induced cell death and indicates that hGHR antagonists may have potential as a novel radiosensitising agent in vivo.
Mechanisms contributing to these observations may be through regulation of cell proliferation and survival. Autocrine hGH promotes cell proliferation and reduces apoptotic cell death in numerous cell models (Perry et al. 2006, Harvey 2010). Binding of hGH to the hGHR activates signal transduction cascades including the PI3K/protein kinase B (AKT) and the MAP kinase cascades, both of which have been implicated in cellular resistance to IR (Liang et al. 2003, LoPiccolo et al. 2007, Begg et al. 2011). Autocrine hGH also protects numerous cell types from apoptosis (Perry et al. 2006, Harvey 2010). We observed here that autocrine hGH reduced the apoptotic response of T47D and MDA-MB-435S cells following radiation exposure. However, apoptotic cell death only plays a modest role in the response of most solid tumours to treatment and whether inhibition of apoptosis contributes to radioresistance in solid tumours remains contentious (Brown \& Attardi 2005, Eriksson \& Stigbrand 2010).

Although exogenous hGH also reduced radiosensitivity, we found that autocrine hGH reduced radiosensitivity more effectively. Differential effects of exogenous (thus mimicking endocrine) vs autocrine hGH in mammary carcinoma have been described by our laboratory in several studies (Xu et al. 2005, Perry et al. 2006, 2008, Brunet-Dunand et al. 2009). The mode of presentation of hGH to the cell may explain why exogenous hGH has disparate effects. Endocrine or pituitary hGH is secreted at high concentrations in a pulsatile manner, which contrasts with the low-level continuous secretion of autocrine hGH at extrapituitary sites. This may lead to either transient or sustained activation of signal transduction pathways and is discussed in previous publications (Perry et al. 2006, 2008, Brunet-Dunand et al. 2009).

DNA damage induced by IR is primarily due to ionisation of water molecules within cells (Sharda et al. 2002). The resulting free radicals, especially the highly reactive hydroxyl radical, can interact with DNA, protein and lipids within a cell causing chemical damage. This form of damage to cells contributes to $\sim 80 \%$ of the lethal effect of IR treatment (Sharda et al. 2002). We demonstrate here that autocrine hGH protected mammary and endometrial carcinoma cells from IR-induced DNA damage. Although we did not observe any effect on the DNA repair capacity using the neutral comet assay, an effect on DNA repair cannot be ruled out. A study by Madrid et al. (2002) demonstrated that the radioprotective effect mediated by exogenous $\mathrm{GH}$ in $\mathrm{CHO}-4$ cells stably expressing the GHR was associated with an enhanced ability of the cells to repair damaged DNA, indicating that GH may 
A

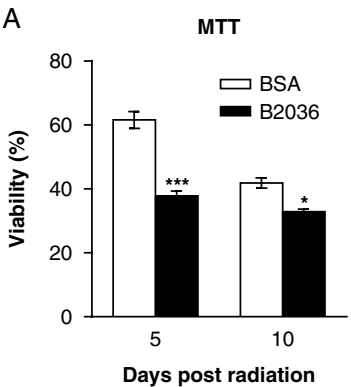

B

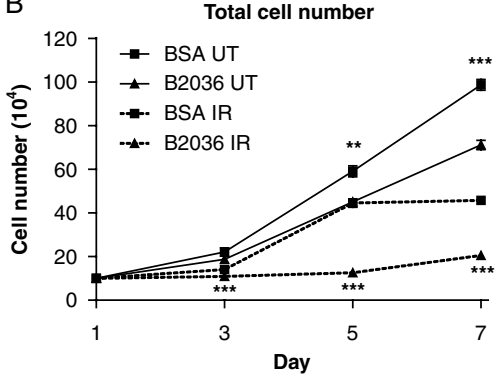

C

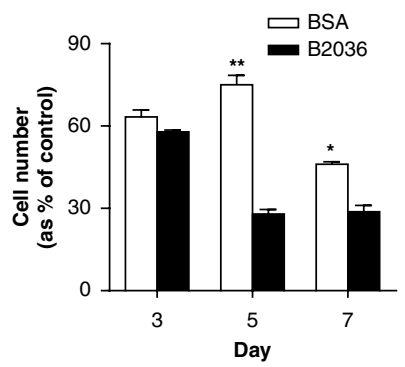

$\mathrm{F}$
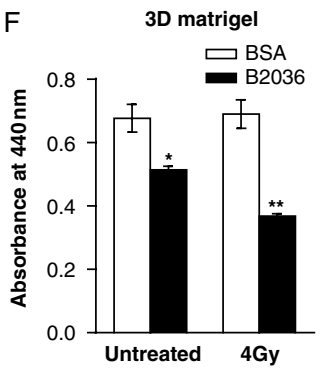

D

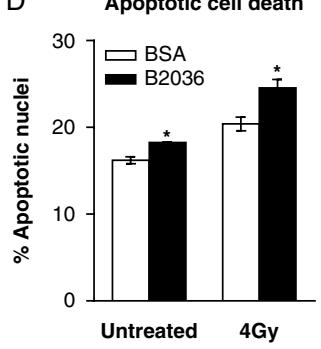

E Clonogenic survival

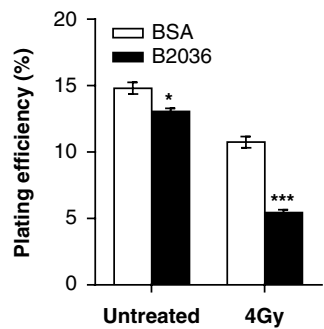

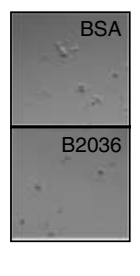

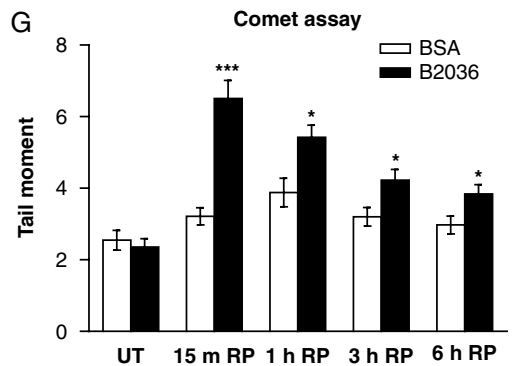

Figure 7 Functional inhibition of hGH in RL95-2 cells increases sensitivity to ionising radiation. RL95-2 cells express hGH endogenously. Cells were treated with either the hGHR antagonist B2036 (1000 nM) or BSA (1000 nM) for $24 \mathrm{~h}$ before treatment with IR. (A) MTT cell viability assay conducted in $10 \%$ serum media at 5 and 10 days post-radiation treatment (4 Gy) compared with BSA-treated control cells. Results are presented as a percentage of the control cells not exposed to IR. (B) Total cell number assay conducted in $10 \%$ serum media over 7 days. (C) Total cell number assay results from (B) presented as percent of untreated control on the indicated days. (D) Apoptotic cell death assay determined by Hoechst 33258 staining. Cells were treated with either B2036 or BSA for $24 \mathrm{~h}$ before treatment with IR and then serum starved for $24 \mathrm{~h}$ before assessing apoptotic nuclei. (E) Clonogenic survival assay. Cells were plated at 400 cells/well, treated with either B2036 or BSA for $24 \mathrm{~h}$ before treatment with $4 \mathrm{~Gy}$ IR and cultured for 14 days in $10 \%$ serum media. (F) Matrigel assay. Cells treated with either B2036 or BSA for $24 \mathrm{~h}$ before treatment with 4 Gy radiation in $5 \%$ FBS media. Cells were cultured for 9 days in media containing $10 \%$ FBS. (G) Neutral comet assay conducted after 4 Gy IR treatment in media containing $10 \%$ FBS $\left({ }^{\star} P<0.05,{ }^{\star \star} P<0.001,{ }^{* \star \star} P<0.0001\right)$. Experiments were repeated at least three times.

A single representative figure is shown.

activate pathways involved in DNA repair processes. Further investigation using assays interrogating different DNA repair pathways would determine whether autocrine hGH impacted on the DNA repair capacity of breast and endometrial cancer cell lines.

Protection against IR-induced DNA damage can also occur through increased cellular levels of thiols such as glutathione (Estrela et al. 2006). GCS is the rate-limiting enzyme for the synthesis of glutathione and increased GCS activity has been shown to be associated with the increased intracellular glutathione levels seen in many drug-resistant cancer cell lines
(Yao et al. 1995). As autocrine hGH increases mRNA levels of GCS in other breast cancer cell lines (Zhu et al. 2005b), we investigated whether autocrine hGH altered the intracellular levels of glutathione in the MDA-MB-435S and T47D cell lines used in this study. However, intracellular glutathione levels were not affected by autocrine hGH in these cell lines indicating that glutathione biosynthesis is unlikely to play a role in the protection against DNA damage afforded by autocrine hGH. Other cellular thiols not investigated here are also known to protect against IR-induced DNA damage and warrant further investigation. 
Another means by which autocrine hGH may protect against DNA damage is by regulating superoxide scavenging enzymes. Autocrine hGH upregulates superoxide dismutase (SOD1) and catalase activity in mammary carcinoma cells in a p44/42 MAP kinasedependant manner (Zhu et al. 2005b). Both enzymes play important roles in the cellular response to the oxidative damage caused by $\gamma$-radiation and certain chemotherapeutic drugs. SOD1 catalyses dismutation of highly damaging superoxide anions to $\mathrm{H}_{2} \mathrm{O}_{2}$ and $\mathrm{O}_{2}$, while catalase decomposes $\mathrm{H}_{2} \mathrm{O}_{2}$ to water and oxygen. The effective elimination of superoxide anions by SOD enzymes has been implicated in protecting cells against DNA damage (Elchuri et al. 2005, Southgate et al. 2006, Tennant \& Kligerman 2011). Thus, regulation of other enzymes involved in oxidant protection may explain the protection afforded by autocrine $\mathrm{hGH}$ against IR-induced DNA damage and cell death and this is the subject of further investigation.

Expression of hTERT in human fibroblasts with short telomeres has been demonstrated to confer resistance to IR, etoposide, hydrogen peroxide and bleomycin (Blasco 2003, Rubio et al. 2004). While telomere length is closely correlated with cancer cell radiosensitivity (Ayouaz et al. 2008). Another mechanism contributing to autocrine hGH-mediated radioresistance may be through the upregulation of telomerase (Emerald et al. 2007). Autocrine hGH has been found to increase $h T E R T$ gene and protein expression, leading to an increase in telomerase activity in MCF-7 cells (Emerald et al. 2007). Consistent with these studies we observed that autocrine hGH increased hTERT mRNA expression in MDA-MB-435S cells (Table 2). Autocrine hGH also induced a modest increase in the level of $B R C A 2$ mRNA in MDA-MB-435S cells. BRCA2 is involved in the repair of radiation-induced DSBs by homologous recombination. It would also be of interest to expand these studies to test other genes involved in DNA repair and the cellular response to radiation.

Another potential mechanism whereby autocrine hGH may mediate radioresistance is through increasing RAD51 protein expression. We observed increased RAD51 protein levels in MDA-hGH vs MDA-vector cell lines and T47D-hGH vs T47D-vec cell lines (Supplementary Figure 1, see section on supplementary data given at the end of this article). RAD51 overexpression has been demonstrated in numerous human tumour cell lines and primary tumour samples (Xia et al. 1997, Ohnishi et al. 1998, Maacke et al. 2000a,b, Collis et al. 2001, Raderschall et al. 2002, Qiao et al. 2005, Richardson 2005) and has been linked to reduced sensitivity to IR in numerous cell types, including breast cancer (Maacke et al. 2000b, Russo et al. 2008, Le Scodan et al. 2010), prostate cancer (Collis et al. 2001) and glioma (Ohnishi et al. 1998). Elevated levels of RAD51 in breast cancer samples correlate with increased invasiveness and poor outcome in patients (Maacke et al. 2000b, Russo et al. 2008, Le Scodan et al. 2010). An increase in RAD51 mRNA expression in MDA-hGH cells was not observed; however, RAD51 protein stability can be regulated post-transcriptionally by caspase-3-mediated proteolytic cleavage. Previous studies have suggested that maintenance of intact RAD51 contributes to abrogation of apoptosis following IR (Huang et al. 1999, Daboussi et al. 2002). In this respect, it is interesting to note that autocrine hGH increased mRNA levels of $B R C A 2$ in MDA-MB-435S cells (Table 2) as BRCA2 has previously been demonstrated to protect RAD51 from proteolytic cleavage by caspase-3 (Brown et al. 2008).

A study by Morante et al. (2003) demonstrated that GH administered subcutaneously to rats prevented radiation injury to healthy intestinal cells, but did not protect colonic-implanted adenocarcinoma cell xenografts, or adenocarcinoma cells grown in culture against IR-induced cell death. In contrast, we observed a clear radioprotective effect mediated by autocrine hGH in three different cancer cell lines. The differential radioprotective effect observed in these studies is unlikely to be due to differences in $\mathrm{GH}$ administration. Although we have previously observed differential effects of exogenous vs autocrine hGH on breast cancer and endothelial cell growth, migratory capacity and gene expression (Xu et al. 2005, Perry et al. 2008, Brunet-Dunand et al. 2009), in the current study, we observed that, similar to autocrine hGH, exogenously added hGH promoted cell regrowth following IR exposure. However, in this regard, autocrine hGH was more effective than hGH added exogenously. The extent to which $\mathrm{GH}$ exerts a protective effect on various cancer cell lines following radiation exposure may therefore be cell line specific.

Our studies indicate that hGHR inhibition may sensitise a subset of hGH-responsive tumours to radiation therapy. However, multiple factors determine whether an agent modulates radiosensitivity in vivo. One point pertinent to this is the pro-angiogenic nature of autocrine hGH. We have previously demonstrated that autocrine hGH increases VEGFA expression in breast cancer cells and enhances tumour vascularisation in mouse xenografts (Brunet-Dunand et al. 2009). Increased tumour VEGFA expression leads to hyperproliferation of blood vessels, which might be expected to improve oxygenation within tumours. However, VEGFA also increases vascular permeability. Thus, 
tumours with high VEGFA typically contain irregular, chaotic networks of leaky microvessels with heterogeneous blood flow and large intervessel distances. Consequently, tumours with high levels of VEGFA, which should act as a compensatory mechanism, continue to have regions of hypoxia (Karar \& Maity 2009, Shinohara \& Maity 2009). Paradoxically, inhibition of VEGFA expression in these tumours can cause the vessels to transiently 'normalise', resulting in decreased interstitial fluid pressure, improved blood flow and increased tumour oxygenation, thus improving radiosensitivity (Karar \& Maity 2009, Shinohara \& Maity 2009). Thus, functional antagonism of $\mathrm{hGH}$ has the potential to radiosensitise tumour cells in vivo; however, this needs to determined experimentally.

As with any therapy, consideration of potential side effects is important. Some indication of potential side effects associated with hGHR antagonism may be obtained from patients with adult-onset GH deficiency, a clinical syndrome characterised by varying degrees of alterations in body composition, decreased bone mass, altered lipid and carbohydrate metabolism, decreased mood and general well-being and in some cases an increase in cardiac risk factors (Mathioudakis \& Salvatori 2008). However, acute treatment regimens involving hGHR antagonism may not induce severe toxicities. Pfizer has conducted a clinical study that evaluated the safety of the hGHR antagonist, pegvisomant, given daily at high doses over several weeks and found that it was generally well tolerated in healthy subjects (Yin et al. 2007).

In conclusion, we have demonstrated that autocrine hGH enhances mammary carcinoma cell survival, clonogenic potential and reduces DNA damage following exposure to IR, while functional inhibition of hGH sensitises cells to IR-induced cell death. Agents capable of functionally antagonising hGH may therefore have clinical relevance as radiosensitising agents in hGH-expressing mammary tumours. Further studies investigating the clinical efficacy of such agents are warranted.

\section{Supplementary data}

This is linked to the online version of the paper at http://dx. doi.org/10.1530/ERC-12-0042.

\section{Declaration of interest}

N M Bougen, M Steiner, M Pertziger, A Banerjee, $\mathrm{S}$ E Brunet-Dunand, T Zhu and J K Perry have nothing to declare; P E Lobie consults for Perseis Therapeutic and is an inventor on U.S. provisional patent application no. 60/940939; and T Zhu and P E Lobie receive financial compensation from and have equity interest in Wuhan Long Ke Ltd.

\section{Funding}

This work was funded by The New Zealand Breast Cancer Foundation (NZBCF), The Breast Cancer Research Trust (NZ) and The Foundation of Science and Technology (NZ).

\section{Acknowledgements}

The authors would like to thank Prof. Bill Wilson for valuable assistance with experimental design, discussion and critical review of the manuscript. They are also grateful to Prof. Alan Ashworth, Dr Mark Vickers and Dr Deborah Sloboda for helpful discussion and supply of materials. They acknowledge the National Research Centre for Growth and Development (NZ) for access to equipment.

\section{References}

Alexandrides T, Spiliotis J, Mylonas P, Melachrinou M, Kardamakis D, Spiliopoulou I, Panagopoulos C \& Kalfarentzos F 1998 Effects of growth hormone and insulin-like growth factor-I on radiation enteritis: a comparative study. European Surgical Research 30 305-311. (doi:10.1159/000008592)

Amiry N, Kong X, Muniraj N, Kannan N, Grandison PM, Lin J, Yang Y, Vouyovitch CM, Borges S, Perry JK et al. 2009 Trefoil factor-1 (TFF1) enhances oncogenicity of mammary carcinoma cells. Endocrinology 150 4473-4483. (doi:10.1210/en.2009-0066)

Ayalon D, Peyser MR, Limor R, Lessing JB \& Ravid R 1982 Paradoxical hypersecretion of growth hormone in patients with endometrial atypical hyperplasia and carcinoma. Effect of hysterectomy. Gynecologic and Obstetric Investigation 13 9-16. (doi:10.1159/000299479)

Ayouaz A, Raynaud C, Heride C, Revaud D \& Sabatier L 2008 Telomeres: hallmarks of radiosensitivity. Biochimie 90 60-72. (doi:10.1016/j.biochi.2007.09.011)

Begg AC, Stewart FA \& Vens C 2011 Strategies to improve radiotherapy with targeted drugs. Nature Reviews. Cancer 11 239-253. (doi:10.1038/nrc3007)

Blasco MA 2003 Mammalian telomeres and telomerase: why they matter for cancer and aging. European Journal of Cell Biology 82 441-446. (doi:10.1078/ 0171-9335-00335)

Bougen NM, Yang T, Chen H, Lobie PE \& Perry JK 2011 Autocrine human growth hormone reduces mammary and endometrial carcinoma cell sensitivity to mitomycin C. Oncology Reports 26 487-493.

Branzei D \& Foiani M 2008 Regulation of DNA repair throughout the cell cycle. Nature Reviews. Molecular Cell Biology 9 297-308. (doi:10.1038/nrm2351) 
Brooks AJ \& Waters MJ 2010 The growth hormone receptor: mechanism of activation and clinical implications. Nature Reviews. Endocrinology 6 515-525. (doi:10.1038/nrendo. 2010.123)

Brown JM \& Attardi LD 2005 The role of apoptosis in cancer development and treatment response. Nature Reviews. Cancer 5 231-237. (doi:10.1038/nrc1560)

Brown ET, Robinson-Benion C \& Holt JT 2008 Radiation enhances caspase 3 cleavage of Rad51 in BRCA2defective cells. Radiation Research 169 595-601. (doi:10.1667/RR1129.1)

Brunet-Dunand SE, Vouyovitch C, Araneda S, Pandey V, Vidal LJ, Print C, Mertani HC, Lobie PE \& Perry JK 2009 Autocrine human growth hormone promotes tumor angiogenesis in mammary carcinoma. Endocrinology 150 1341-1352. (doi:10.1210/en.2008-0608)

Celeste A, Petersen S, Romanienko PJ, Fernandez-Capetillo O, Chen HT, Sedelnikova OA, Reina-San-Martin B, Coppola V, Meffre E, Difilippantonio MJ et al. 2002 Genomic instability in mice lacking histone H2AX. Science 296 922-927. (doi:10.1126/science.1069398)

Chen BJ, Deoliveira D, Spasojevic I, Sempowski GD, Jiang C, Owzar K, Wang X, Gesty-Palmer D, Cline JM, Bourland JD et al. 2010 Growth hormone mitigates against lethal irradiation and enhances hematologic and immune recovery in mice and nonhuman primates. PLoS ONE 5 e11056. (doi:10.1371/journal.pone.0011056)

Chiarenza A, Lempereur L, Palmucci T, Cantarella G, Amico-Roxas M, Goffin V, Murabito P, Magro G \& Bernardini R 2000 Responsiveness of irradiated rat anterior pituitary cells to hypothalamic releasing hormones is restored by treatment with growth hormone. Neuroendocrinology 72 392-399. (doi:10.1159/000054608)

Collis SJ, Tighe A, Scott SD, Roberts SA, Hendry JH \& Margison GP 2001 Ribozyme minigene-mediated RAD51 down-regulation increases radiosensitivity of human prostate cancer cells. Nucleic Acids Research 29 1534-1538. (doi:10.1093/nar/29.7.1534)

Daboussi F, Dumay A, Delacote F \& Lopez BS 2002 DNA double-strand break repair signalling: the case of RAD51 post-translational regulation. Cell Signalling 14 969-975. (doi:10.1016/S0898-6568(02)00052-9)

Dumont F, Altmeyer A \& Bischoff P 2009 Radiosensitising agents for the radiotherapy of cancer: novel molecularly targeted approaches. Expert Opinion on Therapeutic Patents 19 775-799. (doi:10.1517/13543770902967666)

Dutreix M, Cosset J \& Sun JS 2010 Molecular therapy in support to radiotherapy. Mutation Research 704 182-189. (doi:10.1016/j.mrrev.2010.01.001)

Elchuri S, Oberley TD, Qi W, Eisenstein RS, Jackson Roberts L, Van Remmen H, Epstein CJ \& Huang TT 2005 CuZnSOD deficiency leads to persistent and widespread oxidative damage and hepatocarcinogenesis later in life. Oncogene 24 367-380. (doi:10.1038/sj.onc.1208207)

Emerald BS, Chen Y, Zhu T, Zhu Z, Lee KO, Gluckman PD \& Lobie PE 2007 AlphaCP1 mediates stabilization of
hTERT mRNA by autocrine human growth hormone. Journal of Biological Chemistry 282 680-690. (doi:10.1074/jbc.M600224200)

Eriksson D \& Stigbrand T 2010 Radiation-induced cell death mechanisms. Tumour Biology 31 363-372. (doi:10.1007/ s13277-010-0042-8)

Estrela JM, Ortega A \& Obrador E 2006 Glutathione in cancer biology and therapy. Critical Reviews in Clinical Laboratory Sciences 43 143-181. (doi:10.1080/ 10408360500523878)

Gallagher EJ \& Leroith D 2011 Is growth hormone resistance/IGF-1 reduction good for you? Cell Metabolism 13 355-356. (doi:10.1016/j.cmet.2011.03.003)

Gomez-de-Segura IA, Prieto I, Grande AG, Garcia P, Guerra A, Mendez J \& De Miguel E 1998 Growth hormone reduces mortality and bacterial translocation in irradiated rats. Acta Oncologica 37 179-185. (doi:10.1080/028418698429748)

Gray LH, Conger AD, Ebert M, Hornsey S \& Scott OC 1953 The concentration of oxygen dissolved in tissues at the time of irradiation as a factor in radiotherapy. British Journal of Radiology 26 638-648. (doi:10.1259/00071285-26-312-638)

Guevara-Aguirre J, Balasubramanian P, Guevara-Aguirre M, Wei M, Madia F, Cheng CW, Hwang D,

Martin-Montalvo A, Saavedra J, Ingles S et al. 2011 Growth hormone receptor deficiency is associated with a major reduction in pro-aging signaling, cancer, and diabetes in humans. Science Translational Medicine 3 70ra13. (doi:10.1126/scitranslmed.3001845)

Harvey S 2010 Extrapituitary growth hormone. Endocrine 38 335-359. (doi:10.1007/s12020-010-9403-8)

Huang Y, Nakada S, Ishiko T, Utsugisawa T, Datta R, Kharbanda S, Yoshida K, Talanian RV, Weichselbaum R, Kufe D et al. 1999 Role for caspase-mediated cleavage of Rad51 in induction of apoptosis by DNA damage. Molecular and Cellular Biology 19 2986-2997.

Isla A, Budke M, Cacicedo L, Garcia-Grande A, Vazquez-Rodriguez I, De Miguel E \& Perez-Alvarez M 2002 Protective effects of growth hormone en cell cultures of the central nervous system. Revista de Neurología 34 208-211.

Isla A, Budke M, Garcia-Grande A, Gomez de la Riva A, Morales C \& Rey J 2007 Protective effects of the growth hormone $(\mathrm{GH})$ on the irradiated spinal cord in rats. Neurocirugía 18 89-94.

Jameel JKA, Rao VSR, Cawkwell L \& Drew PJ 2004 Radioresistance in carcinoma of the breast. Breast 13 452-460. (doi:10.1016/j.breast.2004.08.004)

Jeggo P \& Lobrich M 2006 Radiation-induced DNA damage responses. Radiation Protection Dosimetry 122 124-127. (doi:10.1093/rpd/ncl495)

Karar J \& Maity A 2009 Modulating the tumor microenvironment to increase radiation responsiveness. Cancer Biology \& Therapy 8 1994-2001. (doi:10.4161/cbt.8.21. 9988) 
Kaulsay KK, Zhu T, Bennett W, Lee KO \& Lobie PE 2001 The effects of autocrine human growth hormone (hGH) on human mammary carcinoma cell behavior are mediated via the hGH receptor. Endocrinology 142 767-777. (doi:10.1210/en.142.2.767)

Kleinberg DL, Wood TL, Furth PA \& Lee AV 2009 Growth hormone and insulin-like growth factor-I in the transition from normal mammary development to preneoplastic mammary lesions. Endocrine Reviews 30 51-74. (doi:10.1210/er.2008-0022)

Kopchick JJ, Parkinson C, Stevens EC \& Trainer PJ 2002 Growth hormone receptor antagonists: discovery, development, and use in patients with acromegaly. Endocrine Reviews 23 623-646. (doi:10.1210/er.2001-0022)

van der Lely AJ \& Kopchick JJ 2006 Growth hormone receptor antagonists. Neuroendocrinology 83 264-268. (doi:10.1159/000095537)

Lempereur L, Brambilla D, Scoto GM, D’Alcamo M, Goffin V, Crosta L, Palmucci T, Rampello L, Bernardini R \& Cantarella G 2003 Growth hormone protects human lymphocytes from irradiation-induced cell death. British Journal of Pharmacology 138 1411-1416. (doi:10.1038/ sj.bjp.0705173)

Le Scodan R, Cizeron-Clairac G, Fourme E, Meseure D, Vacher S, Spyratos F, de la Lande B, Cvitkovic F, Lidereau R \& Bieche I 2010 DNA repair gene expression and risk of locoregional relapse in breast cancer patients. International Journal of Radiation Oncology, Biology, Physics 78 328-336. (doi:10.1016/j.ijrobp.2009. 07.1735)

Liang K, Jin W, Knuefermann C, Schmidt M, Mills GB, Ang KK, Milas L \& Fan Z 2003 Targeting the phosphatidylinositol 3-kinase/Akt pathway for enhancing breast cancer cells to radiotherapy. Molecular Cancer Therapeutics 2 353-360.

Ling L, Zhu T \& Lobie PE 2003 Src-CrkII-C3G-dependent activation of Rap1 switches growth hormone-stimulated p44/42 MAP kinase and JNK/SAPK activities. Journal of Biological Chemistry 278 27301-27311. (doi:10.1074/ jbc.M302516200)

van de Loosdrecht AA, Beelen RH, Ossenkoppele GJ, Broekhoven MG \& Langenhuijsen MM 1994 A tetrazolium-based colorimetric MTT assay to quantitate human monocyte mediated cytotoxicity against leukemic cells from cell lines and patients with acute myeloid leukemia. Journal of Immunological Methods 174 311-320. (doi:10.1016/0022-1759(94)90034-5)

LoPiccolo J, Granville CA, Gills JJ \& Dennis PA 2007 Targeting Akt in cancer therapy. Anti-Cancer Drugs 18 861-874.

Maacke H, Jost K, Opitz S, Miska S, Yuan Y, Hasselbach L, Luttges J, Kalthoff H \& Sturzbecher HW $2000 a$ DNA repair and recombination factor $\operatorname{Rad} 51$ is overexpressed in human pancreatic adenocarcinoma. Oncogene 19 2791-2795. (doi:10.1038/sj.onc. 1203578)
Maacke H, Opitz S, Jost K, Hamdorf W, Henning W, Kruger S, Feller AC, Lopens A, Diedrich K, Schwinger E et al. 2000 b Over-expression of wild-type Rad51 correlates with histological grading of invasive ductal breast cancer. International Journal of Cancer 88 907-913. (doi:10.1002/1097-0215(20001215)88:6<907::AIDIJC11>3.0.CO;2-4)

MacPhail SH, Banath JP, Yu TY, Chu EH, Lambur H \& Olive PL 2003 Expression of phosphorylated histone $\mathrm{H} 2 \mathrm{AX}$ in cultured cell lines following exposure to X-rays. International Journal of Radiation Biology 79 351-358. (doi:10.1080/0955300032000093128)

Madrid O, Varea S, Sanchez-Perez I, Gomez-Garcia L, De Miguel E, Gomez De Segura IA \& Perona R 2002 Growth hormone protects against radiotherapy-induced cell death. European Journal of Endocrinology 147 535-541. (doi:10.1530/eje.0.1470535)

Mathioudakis N \& Salvatori R 2008 Adult-onset growth hormone deficiency: causes, complications and treatment options. Current Opinion in Endocrinology, Diabetes and Obesity 15 352-358.

Mertani HC, Zhu T, Goh EL, Lee KO, Morel G \& Lobie PE 2001 Autocrine human growth hormone $(\mathrm{hGH})$ regulation of human mammary carcinoma cell gene expression. Identification of CHOP as a mediator of hGH-stimulated human mammary carcinoma cell survival. Journal of Biological Chemistry 276 21464-21475. (doi:10.1074/ jbc.M100437200)

Morante J, Vallejo-Cremades MT, Gomez-Garcia L, Vazquez I, Gomez-de-Segura IA, Sanchez M \& De Miguel E 2003 Differential action of growth hormone in irradiated tumoral and nontumoral intestinal tissue. Digestive Diseases and Sciences 48 2159-2166. (doi:10.1023/B:DDAS.0000004520.71462.c9)

Mukhina S, Mertani HC, Guo K, Lee KO, Gluckman PD \& Lobie PE 2004 Phenotypic conversion of human mammary carcinoma cells by autocrine human growth hormone. PNAS 101 15166-15171. (doi:10.1073/pnas. 0405881101)

Mylonas PG, Matsouka PT, Papandoniou EV, Vagianos C, Kalfarentzos F \& Alexandrides TK 2000 Growth hormone and insulin-like growth factor I protect intestinal cells from radiation induced apoptosis. Molecular and Cellular Endocrinology 160 115-122. (doi:10.1016/ S0303-7207(99)00215-4)

Nordsmark M, Bentzen SM, Rudat V, Brizel D, Lartigau E, Stadler P, Becker A, Adam M, Molls M, Dunst J et al. 2005 Prognostic value of tumor oxygenation in 397 head and neck tumors after primary radiation therapy. An international multi-center study. Radiotherapy and Oncology 77 18-24. (doi:10.1016/j.radonc.2005.06.038)

Ohnishi T, Taki T, Hiraga S, Arita N \& Morita T 1998 In vitro and in vivo potentiation of radiosensitivity of malignant gliomas by antisense inhibition of the RAD51 gene. Biochemical and Biophysical Research Communications 245 319-324. (doi:10.1006/bbrc.1998.8440) 
Olive PL \& Banath JP 2006 The comet assay: a method to measure DNA damage in individual cells. Nature Protocols 1 23-29. (doi:10.1038/nprot.2006.5)

Pandey V, Perry JK, Mohankumar KM, Kong XJ, Liu SM, Wu ZS, Mitchell MD, Zhu T \& Lobie PE 2008 Autocrine human growth hormone stimulates oncogenicity of endometrial carcinoma cells. Endocrinology 149 3909-3919. (doi:10.1210/en.2008-0286)

Paull TT, Rogakou EP, Yamazaki V, Kirchgessner CU, Gellert M \& Bonner WM 2000 A critical role for histone $\mathrm{H} 2 \mathrm{AX}$ in recruitment of repair factors to nuclear foci after DNA damage. Current Biology 10 886-895. (doi:10.1016/S0960-9822(00)00610-2)

Perry JK, Emerald BS, Mertani HC \& Lobie PE 2006 The oncogenic potential of growth hormone. Growth Hormone \& IGF Research 16 277-289. (doi:10.1016/ j.ghir.2006.09.006)

Perry JK, Mohankumar KM, Emerald BS, Mertani HC \& Lobie PE 2008 The contribution of growth hormone to mammary neoplasia. Journal of Mammary Gland Biology \& Neoplasia 13 131-145. (doi:10.1007/s10911-0089070-z)

Qiao GB, Wu YL, Yang XN, Zhong WZ, Xie D, Guan XY, Fischer D, Kolberg HC, Kruger S \& Stuerzbecher HW 2005 High-level expression of Rad51 is an independent prognostic marker of survival in non-small-cell lung cancer patients. British Journal of Cancer 93 137-143. (doi:10.1038/sj.bjc.6602665)

Raderschall E, Stout K, Freier S, Suckow V, Schweiger S \& Haaf T 2002 Elevated levels of Rad51 recombination protein in tumor cells. Cancer Research 62 219-225.

Raguso CA, Leverve X \& Pichard C 2002 Protective effects of recombinant growth hormone on intestinal mucosa in rats receiving abdominal radiotherapy. Clinical Nutrition 21 487-490. (doi:10.1054/clnu.2002.0579)

Richardson C 2005 RAD51, genomic stability, and tumorigenesis. Cancer Letters 218 127-139. (doi:10.1016/j. canlet.2004.08.009)

Rogakou EP, Pilch DR, Orr AH, Ivanova VS \& Bonner WM 1998 DNA double-stranded breaks induce histone H2AX phosphorylation on serine 139. Journal of Biological Chemistry 273 5858-5868. (doi:10.1074/jbc.273.10.5858)

Rubio MA, Davalos AR \& Campisi J 2004 Telomere length mediates the effects of telomerase on the cellular response to genotoxic stress. Experimental Cell Research 298 17-27. (doi:10.1016/j.yexcr.2004.04.004)

Russo AL, Citrin D \& Camphausen K 2008 Biomarkers in radiation oncology. Biomarkers in Medicine 2 155-163. (doi:10.2217/17520363.2.2.155)

Sharda N, Yang C-R, Kinsella T \& Boothman D 2002 Radiation resistance. In Encyclopedia of Cancer. San Diego, CA, USA: Academic Press.

Shevah O \& Laron Z 2007 Patients with congenital deficiency of IGF-I seem protected from the development of malignancies: a preliminary report. Growth Hormone \& IGF Research 17 54-57. (doi:10.1016/j.ghir. 2006.10.007)
Shinohara ET \& Maity A 2009 Increasing sensitivity to radiotherapy and chemotherapy by using novel biological agents that alter the tumor microenvironment. Current Molecular Medicine 9 1034-1045. (doi:10.2174/ 156652409789839107)

Slater M, Cooper M \& Murphy CR 2006 Human growth hormone and interleukin-6 are upregulated in endometriosis and endometrioid adenocarcinoma. Acta Histochemica 108 13-18. (doi:10.1016/j.acthis.2006.01.004)

Southgate TD, Sheard V, Milsom MD, Ward TH, Mairs RJ, Boyd M \& Fairbairn LJ 2006 Radioprotective gene therapy through retroviral expression of manganese superoxide dismutase. Journal of Gene Medicine $\mathbf{8}$ 557-565. (doi:10.1002/jgm.890)

Steuerman R, Shevah O \& Laron Z 2011 Congenital IGF1 deficiency tends to confer protection against postnatal development of malignancies. European Journal of Endocrinology 164 485-489. (doi:10.1530/EJE-10-0859)

Stiff T, O'Driscoll M, Rief N, Iwabuchi K, Lobrich M \& Jeggo PA 2004 ATM and DNA-PK function redundantly to phosphorylate H2AX after exposure to ionizing radiation. Cancer Research 64 2390-2396. (doi:10.1158/ 0008-5472.CAN-03-3207)

Tanaka T, Kurose A, Huang X, Traganos F, Dai W \& Darzynkiewicz Z 2006 Extent of constitutive histone H2AX phosphorylation on Ser-139 varies in cells with different TP53 status. Cell Proliferation 39 313-323. (doi:10.1111/j.1365-2184.2006.00387.x)

Tekin SB, Ertekin MV, Erdogan F, Sezen O, Karslioglu I, Gepdiremen A, Serifoglu K \& Altas S 2006 Is growth hormone a radioprotective agent? Journal of the European Academy of Dermatology and Venereology 20 293-298. (doi:10.1111/j.1468-3083.2006.01454.x)

Tennant AH \& Kligerman AD 2011 Superoxide dismutase protects cells from DNA damage induced by trivalent methylated arsenicals. Environmental and Molecular Mutagenesis 52 238-243. (doi:10.1002/em. 20609)

Vazquez I, Gomez-de-Segura IA, Grande AG, Escribano A, Gonzalez-Gancedo P, Gomez A, Diez R \& De Miguel E 1999 Protective effect of enriched diet plus growth hormone administration on radiation-induced intestinal injury and on its evolutionary pattern in the rat. Digestive Diseases and Sciences 44 2350-2358. (doi:10.1023/ A:1026637611298)

Wu X, Wan M, Li G, Xu Z, Chen C, Liu F \& Li J 2006 Growth hormone receptor overexpression predicts response of rectal cancers to pre-operative radiotherapy. European Journal of Cancer 42 888-894. (doi:10.1016/j. ejca.2005.12.012)

Wu ZS, Yang K, Wan Y, Qian PX, Perry JK, Chiesa J, Mertani HC, Zhu T \& Lobie PE 2011 Tumor expression of human growth hormone and human prolactin predict a worse survival outcome in patients with mammary or endometrial carcinoma. Journal of Clinical Endocrinology and Metabolism 96 E1619-E1629. (doi:10.1210/jc.2011-1245) 
Xia SJ, Shammas MA \& Shmookler Reis RJ 1997 Elevated recombination in immortal human cells is mediated by HsRAD51 recombinase. Molecular and Cellular Biology 17 7151-7158.

Xu XQ, Emerald BS, Goh ELK, Kannan N, Miller LD, Gluckman PD, Liu ET \& Lobie PE 2005 Gene expression profiling to identify oncogenic determinants of autocrine human growth hormone in human mammary carcinoma. Journal of Biological Chemistry 280 23987-24003. (doi:10.1074/jbc. M503869200)

Yao KS, Godwin AK, Johnson SW, Ozols RF, O’Dwyer PJ \& Hamilton TC 1995 Evidence for altered regulation of gamma-glutamylcysteine synthetase gene expression among cisplatin-sensitive and cisplatin-resistant human ovarian cancer cell lines. Cancer Research $\mathbf{5 5}$ 4367-4374.

Yin D, Vreeland F, Schaaf LJ, Millham R, Duncan BA \& Sharma A 2007 Clinical pharmacodynamic effects of the growth hormone receptor antagonist pegvisomant: implications for cancer therapy. Clinical Cancer Research 13 1000-1009. (doi:10.1158/1078-0432.CCR06-1910)

Yurkovetsky Z, Ta'asan S, Skates S, Rand A, Lomakin A, Linkov F, Marrangoni A, Velikokhatnaya L, Winans M,
Gorelik E et al. 2007 Development of multimarker panel for early detection of endometrial cancer. High diagnostic power of prolactin. Gynecologic Oncology 107 58-65. (doi:10.1016/j.ygyno.2007. 05.041)

Zaidi SH, Huddart RA \& Harrington KJ 2009 Novel targeted radiosensitisers in cancer treatment. Current Drug Discovery Technologies 6 103-134. (doi:10.2174/ 157016309788488348)

Zhu T, Starling-Emerald B, Zhang X, Lee KO, Gluckman PD, Mertani HC \& Lobie PE 2005a Oncogenic transformation of human mammary epithelial cells by autocrine human growth hormone. Cancer Research 65 317-324.

Zhu Z, Mukhina S, Zhu T, Mertani HC, Lee K-O \& Lobie PE $2005 \mathrm{~b}$ p44/42 MAP kinase-dependent regulation of catalase by autocrine human growth hormone protects human mammary carcinoma cells from oxidative stress-induced apoptosis. Oncogene 24 3774-3785. (doi:10.1038/sj.onc.1208541)

Received in final form 10 July 2012 Accepted 16 July 2012 Made available online as an Accepted Preprint 17 July 2012 